\title{
Glycine Metabolism and Its Alterations in Obesity and Metabolic Diseases
}

\author{
Anaïs Alves ${ }^{1}$, Arthur Bassot ${ }^{1}$, Anne-Laure Bulteau ${ }^{2}$, Luciano Pirola ${ }^{1}$ (D) and Béatrice Morio ${ }^{1,3, *(\mathbb{D})}$ \\ 1 Université de Lyon, Laboratoire de Recherche en Cardiovasculaire Métabolisme Diabétologie et Nutrition, \\ Institut National de la Santé et de la Recherche Médicale, Institut National de la Recherche Agronomique, \\ Institut National des Sciences Appliquées de Lyon, Université Claude Bernard Lyon 1, Unite Mixte de \\ Recherche 1060, 69310 Pierre Bénite, France; anais.alves@etu.univ-lyon1.fr (A.A.); \\ arthur.bassot@etu.univ-lyon1.fr (A.B.); luciano.pirola@inserm.fr (L.P.) \\ 2 Université de Lyon, Institut de Génomique Fonctionnelle de Lyon, Ecole Normale Superieure de Lyon, \\ Centre National de la Recherche Scientifique, Université Claude Bernard Lyon 1, Unite Mixte de Recherche \\ 5242, 69007 Lyon, France; anne-laure.bulteau@ens-lyon.fr \\ 3 INRA U1397-INSERM U1060-Laboratoire CarMeN, Hôpital Lyon Sud secteur 2, bâtiment Cens-Eli D, \\ 165 Chemin du Grand Revoyet, 69310 Pierre Bénite, France \\ * Correspondence: beatrice.morio@inra.fr; Tel.: +33-426-235-948
}

Received: 10 May 2019; Accepted: 12 June 2019; Published: 16 June 2019

\begin{abstract}
Glycine is the proteinogenic amino-acid of lowest molecular weight, harboring a hydrogen atom as a side-chain. In addition to being a building-block for proteins, glycine is also required for multiple metabolic pathways, such as glutathione synthesis and regulation of one-carbon metabolism. Although generally viewed as a non-essential amino-acid, because it can be endogenously synthesized to a certain extent, glycine has also been suggested as a conditionally essential amino acid. In metabolic disorders associated with obesity, type 2 diabetes (T2DM), and non-alcoholic fatty liver disease (NAFLDs), lower circulating glycine levels have been consistently observed, and clinical studies suggest the existence of beneficial effects induced by glycine supplementation. The present review aims at synthesizing the recent advances in glycine metabolism, pinpointing its main metabolic pathways, identifying the causes leading to glycine deficiency-especially in obesity and associated metabolic disorders-and evaluating the potential benefits of increasing glycine availability to curb the progression of obesity and obesity-related metabolic disturbances. This study focuses on the importance of diet, gut microbiota, and liver metabolism in determining glycine availability in obesity and associated metabolic disorders.
\end{abstract}

Keywords: amino acid metabolism; gut-liver axis; pathophysiology of metabolic disorders; nutritional prevention

\section{Introduction}

Glycine is the protein-forming amino acid with the smallest molecular weight $\left(\mathrm{NH}_{2}-\mathrm{CH}_{2}-\mathrm{COOH}\right.$; $75.067 \mathrm{~g} / \mathrm{mol}$ ). The hydrogen in the glycine's side chain allows it to integrate both hydrophilic and hydrophobic environments within the polypeptide chain. Although glycine can be endogenously produced, studies in several animal models support the notion that glycine may be conditionally essential [1], as the amount of glycine synthesized in vivo may sometimes be insufficient to meet the organism's metabolic needs [2-4]. Chronic glycine insufficiency may impact health status in the long term. Indeed, glycine, besides being a protein's building block, is also a bioactive amino acid that participates in the regulation of gene expression [5,6], protein configuration and activity [6], and several biological functions, such as glutathione synthesis [7]. Low plasma glycine concentrations have been consistently reported in association with obesity, T2DM, and NAFLDs [8,9]. These observations suggest 
that in the long term, mild deficiency in glycine may participate in the etiology of metabolic diseases (Table 1). Therefore, the aim of this review is to summarize the evidence supporting this hypothesis.

The following points will be emphasized: (1) situating glycine metabolism in a context of the physiopathology of metabolic diseases associated with obesity (insulin resistance, T2DM, and NAFLDs); (2) understanding the potential causes of decreased glycine availability in these situations; and (3) summarizing the current knowledge on the benefits of improving glycine availability through dietary supplementation. The present review broadens the scope of previously published reviews [10-13] by integrating the importance of dietary patterns, the contribution of the gut microbiota, and the interaction with host metabolism in determining glycine availability. 
Table 1. Summary of key observational studies correlating glycine serum or plasma levels to metabolic disease.

\begin{tabular}{|c|c|c|c|c|c|}
\hline \multirow{2}{*}{ Study Group } & \multirow{2}{*}{ Health Status } & \multicolumn{2}{|c|}{ Glycine Concentration $(\mu \mathrm{mol} / \mathrm{L})$} & \multirow{2}{*}{ Level of Significance } & \multirow{2}{*}{ Reference } \\
\hline & & Control Group & Study Group & & \\
\hline $\begin{array}{l}20 \text { control subjects, } 15 \text { subjects with } \\
\text { obesity with NAFLD }\end{array}$ & Controls vs. obesity with NAFLD & Mean: $205.9 \pm 9.7$ & $\begin{array}{l}\text { Mean obesity with NAFLD: } \\
179.2 \pm 7.6\end{array}$ & $p=0.03$ & [9] \\
\hline $\begin{array}{l}\text { The observational, prospective } \\
\text { cohort PPSDiab: } 151 \text { women with } \\
\text { gestational diabetes or } \\
\text { normoglycemia during pregnancy }\end{array}$ & NGT vs. PGT & Median NGT: 272.6 & Median PGT: 224.6 & $p<0.01$ & [14] \\
\hline 399 nondiabetic adults & IS vs. IR & NA & 0.85 fold vs. controls & $p=2.79 \times 10^{-11}$ & [15] \\
\hline $\begin{array}{l}124 \text { adults (63 European American } \\
\text { and } 60 \text { African American) }\end{array}$ & IS vs. IR and T2DM & Mean IS: 306.8 & $\begin{array}{c}\text { Mean IR: } 257.0 \\
\text { Mean T2DM: } 246.8 \\
\text { [Glycine concentration was } \\
\text { correlated to GDR in a } \\
\text { hyperinsulinemic-euglycemic clamp] }\end{array}$ & $\begin{array}{l}p<0.01 \text { for the two } \\
\text { comparisons vs. IS }\end{array}$ & [16] \\
\hline 64 adults & $\begin{array}{c}\text { sex-matched groups for BMI } \\
\text { [lean vs. morbid obesity] and risk } \\
\text { of developing T2DM [IS vs. IR] }\end{array}$ & & $\begin{array}{l}\text { Glycine concentration is negatively } \\
\text { associated to fasting insulin and } \\
\text { HOMA-IR }\end{array}$ & $\begin{array}{c}\mathrm{R}=-0.51, p=0.0017 ; \text { and } \\
\mathrm{R}=-0.49, p=0.0033\end{array}$ & [17] \\
\hline $\begin{array}{c}\text { Framingham Heart Study } \\
(n=1015) \text { and the Malmö Diet and } \\
\text { Cancer Study }(n=746)\end{array}$ & $\begin{array}{l}45 \% \text { of individuals meeting the } \\
\text { criteria for metabolic syndrome }\end{array}$ & Mean NGT = 270 & Mean PGT = 220 & $p=0.0005$ & [18] \\
\hline $\begin{array}{c}73 \text { control subjects, } 10 \text { subjects with } \\
\text { obesity }\end{array}$ & Controls vs. obesity & Mean: $223.7 \pm 33.0$ & Mean: $197.9 \pm 41.4$ & $p=0.027$ & [19] \\
\hline $\begin{array}{c}51 \text { healthy control subjects; } 31 \\
\text { overweight or obese subjects; } 52 \\
\text { subjects with T2DM }\end{array}$ & $\begin{array}{l}\text { Controls vs. obesity and T2DM } \\
\text { Men and women were analyzed } \\
\text { separately }\end{array}$ & $\begin{array}{c}\text { Mean men: } 211 \pm 30 \\
\text { Mean women: } 231 \pm 67\end{array}$ & $\begin{array}{l}\text { Mean men with obesity: } 186 \pm 30 \\
\text { Mean men with T2DM: } 187 \pm 44 \\
\text { Mean women with obesity: } 203 \pm 48 \\
\text { Mean women with T2DM: } 184 \pm 48\end{array}$ & $\begin{array}{c}p<0.05 \text { for all } \\
\text { comparisons vs. controls }\end{array}$ & [20] \\
\hline
\end{tabular}




\section{Glycine Dietary Intake and Metabolism}

Glycine dietary intake varies from 1.5 to $3 \mathrm{~g} /$ day depending on the protein intake of the individual. Glycine content in the protein fraction of different dietary sources is relatively uniform, except for rice, which is about twice as rich in glycine as compared to other proteins from animal or vegetable origins [21]. The multicentric European Prospective Investigation into Cancer and Nutrition (EPIC) study has shown that the average daily intake of glycine (adjusted for age, body mass index, smoking status, and alcohol intake) varies from 2.28 to $3.12 \mathrm{~g} /$ day in adult males with different patterns of dietary protein sources (meat or fish eaters, vegetarians or vegans) [22]. The interaction between glycine dietary intake and its endogenous biosynthetic and catabolic pathways is crucial in determining the ability of an individual to meet their needs (Figure 1). To begin with, we will first briefly examine the biochemical principles and highlight the relative importance of the main endogenous pathways of glycine synthesis and degradation. These pathways have been recently thoroughly reviewed by Adeva-Andany et al. [11].

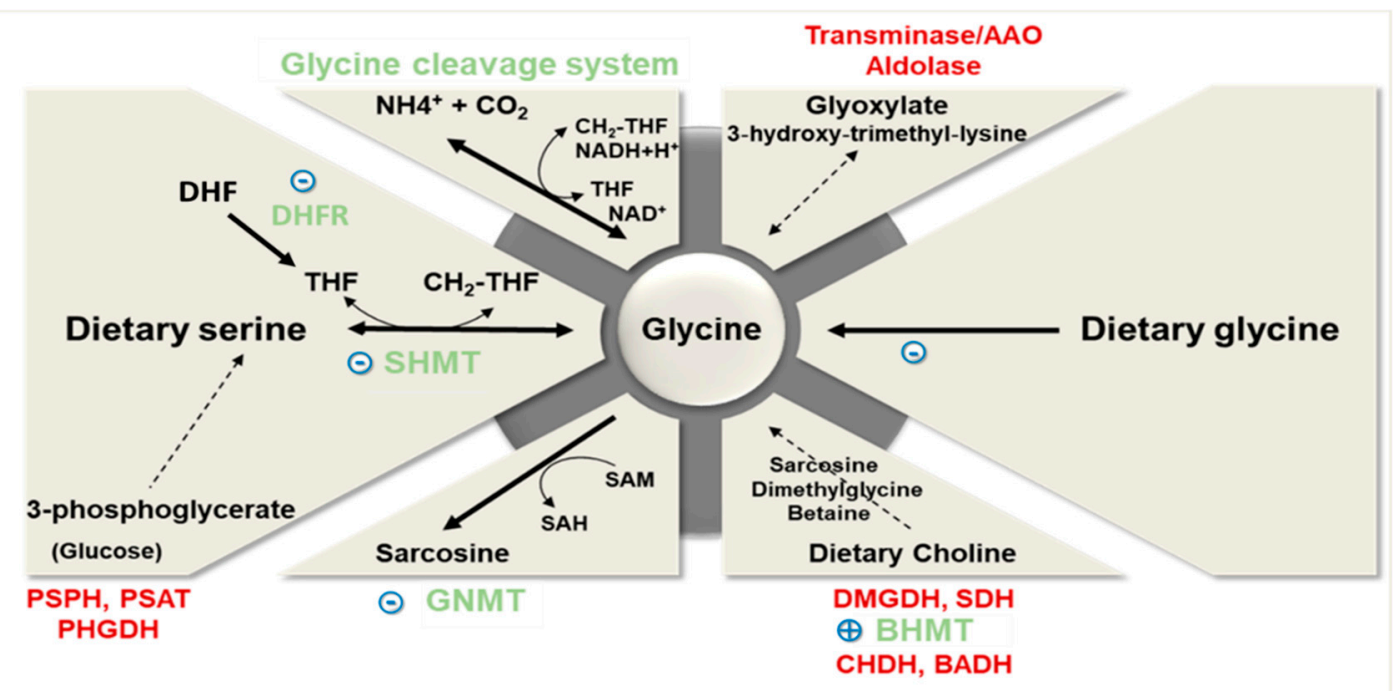

Figure 1. Main dietary sources and metabolic pathways of glycine. (Enzymes with a quantitatively prominent significant physiological role are presented in gray). Note: $\mathrm{AAO}=\mathrm{D}$-amino acid oxidase; BHMT = betaine-homocysteine S-methyltransferase; $\mathrm{CHDH}=$ choline dehydrogenase; $\mathrm{DHF}=$ dihydrofolate; $\mathrm{DHFR}=$ dihydrofolate reductase; $\mathrm{DMGDH}=$ dimethylglycine dehydrogenase; GNMT = glycine $\mathrm{N}$-methyltransferase; $\mathrm{PHGDH}$ = phosphoglycerate dehydrogenase; PSAT = phosphoserine aminotransferase; PSPH = phosphoserine phosphatase; SAM = S-adenosylmethionine; $\mathrm{SAH}=$ S-adenosylhomocysteine; $\mathrm{SDH}=$ sarcosine dehydrogenase; SHMT = serine hydroxymethyltransferase; $\mathrm{THF}=$ tetrahydrofolate; $\mathrm{CH}_{2}-\mathrm{THF}=\mathrm{N}^{5}, \mathrm{~N}^{10}$-methylene tetrahydrofolate. Labels in blue evidence the obesity-associated alterations in the expression or activity of the main enzymes determining glycine availability (for details see text in Section 2). Dietary glycine availability and uptake by the organism is regulated by the microbiota and gut metabolism (for details, see text in Section 3).

\subsection{Glycine Synthesis}

Using isotopic tracers in young men, whole body glycine flux was estimated to average $34-35 \mathrm{mg} / \mathrm{kg} / \mathrm{h}$ in the fed state [2,23]. Of this systemic flux, 35\% of the glycine comes from endogenous synthesis [3]. In the post-absorptive state, whole body glycine flux is decreased by half and reaches around $18 \mathrm{mg} / \mathrm{kg} / \mathrm{h}[23,24]$, with de novo synthesized glycine contributing to $81 \%$ of the systemic flux [24]. The average rate of whole body glycine de novo synthesis could, thus, be estimated at 12 to $15 \mathrm{mg} / \mathrm{kg} / \mathrm{h}$. This rate can be decreased when non-essential amino acid intake is reduced [3], but it is only slightly affected by total amino acid intake [3], hyperglycemia, or hyperinsulinemia [24,25]. 
Glycine is mainly synthesized from serine, threonine (in most mammals but not in humans; [26]), choline, sarcosine ( $\mathrm{N}$-methylglycine), and glyoxylate, and during endogenous synthesis of L-carnitine (Figure 1). Theoretical calculations have determined that serine and its precursors are the main contributors to the endogenous production of glycine. Serine contributes to the synthesis of approximately $2.5 \mathrm{~g}$ of glycine/d, which is close to the mean dietary intake of glycine discussed above [4]. Collectively, the other biosynthetic pathways contribute to the endogenous production of glycine to a much lesser extent (less than $15 \%$ of the serine contribution) [4].

In healthy individuals, glycine is inter-convertible with serine (Figure 1). Serine is mostly derived from the diet, but it can also be produced from glucose via 3-phosphoglycerate, especially in kidneys. Glycine synthesis from serine is compartmentalized, being catalyzed by serine hydroxymethyltransferase 1 (SHMT1) in the cytosol and by SHMT2 in the mitochondrial matrix [27]. While SHMTs are ubiquitously expressed, most of the SHMT-dependent glycine synthesis occurs within the liver, mainly via mitochondrial SHMT2. A prior study indeed showed that mitochondrial isoform of SHMT and intracellular serine concentration regulate the rate of glycine synthesis in mutant lines of cultured Chinese hamster ovary cells [28]. SHMT activity requires two cofactors, pyridoxal phosphate and tetrahydrofolate (THF). Theoretical calculations suggest that the stoichiometry of this reaction may be the limiting step of glycine synthesis and may explain why the in vivo synthesis rate of glycine may become insufficient to meet the metabolic needs [29]. More specifically, stoichiometry of the reaction catalyzed by SHMT requires glycine and 5,10-methylene tetrahydrofolate $\left(\mathrm{CH}_{2}\right.$-THF) to be produced in equimolar amounts, regardless of differences in the metabolic needs for the two molecules. Since the methylene unit $\left(\mathrm{CH}_{2}\right)$ must be released from $\mathrm{CH}_{2}-\mathrm{THF}$ before THF can be reused for glycine synthesis [30], the flux of methyl transfers must match the needs for glycine synthesis and also that of glycine catabolism by the cleavage system. SHMT in human placenta has been pointed out as an important enzyme to cover glycine needs for fetal growth [31]. However, alterations in the rate of conversion of serine to glycine have not been reported yet in obesity and associated metabolic disorders. Decrease in the plasma level of serine reported in those conditions [30,32], although not consistently [9], may suggest a potential reduction in the activity of this pathway.

Glycine synthesis from the choline biosynthetic pathway [33] is not predominant as dietary choline intake is very low $(400-500 \mathrm{mg} / \mathrm{d})$. However, this pathway is relevant because it also intervenes in the regulation of methyl donor availability, and consequently, in cellular methylation processes. Choline-dependent glycine biosynthesis involves the intermediary metabolites betaine (trimethylglycine), dimethylglycine, and sarcosine ( $N$-methylglycine), as illustrated in Figure 1. The enzymes regulating the methyl transfers in the production of glycine from betaine are successively the cytosolic enzyme betaine-homocysteine S-methyltransferase (BHMT), and the mitochondrial enzymes dimethylglycine dehydrogenase (DMGDH) and sarcosine dehydrogenase (SDH). Interestingly, expression of BHMT, which catalyzes the methyl transfer from betaine to homocysteine to produce dimethylglycine and methionine, was shown to be upregulated in the liver of high-fat fed mice [34,35].

In the liver, glycine can also be produced from the conversion of glyoxylate by alanine:glyoxylate aminotransferase (AGXT), which simultaneously converts alanine to pyruvate [36]. AGXT is mainly present in peroxisomes in humans and plays a key role in limiting the rate of oxalate synthesis. Glyoxylate is produced as a byproduct of the pentose phosphate pathway or the breakdown of serine and hydroxyproline.

The enzyme dihydrofolate reductase (DHFR) is a key enzyme in cell replication. It catalyzes the recovery of tetrahydrofolate, which is an essential reaction for the de novo synthesis of glycine, among others [37]. Interestingly, isolation of Chinese hamster cell mutants showed that mutant cells that no longer express DHFR require glycine to survive [38]. Downregulation of DHFR protein expression and of metabolites from the vitamin B group have been reported in the liver of high-fat fed mice [39]. In addition, vascular DHFR protein content was decreased in $\mathrm{db} / \mathrm{db}$ mice compared with $\mathrm{db} / \mathrm{m}$ mice [40]. 
Finally, hepatic de novo synthesis of glycine is catalyzed by glycine synthase, also called glycine cleavage enzyme [41]. This enzymatic system is composed of four mitochondrial protein components: P protein (a pyridoxal phosphate-dependent glycine decarboxylase), $\mathrm{H}$ protein (a lipoic acid-containing protein), T protein (a tetrahydrofolate-requiring enzyme), and L protein (a lipoamide dehydrogenase). Glycine synthase catalysis is reversible and participates in the hepatic catabolism of glycine (see below) (Figure 1).

\subsection{Glycine Catabolism}

Dietary glycine is rapidly converted to serine by the cytosolic SHMT1. This pathway accounts for almost half of the whole body glycine flux [23] and is a quantitatively major acceptor of methyl groups from $\mathrm{CH}_{2}$-THF. In young men, tracking the fate of orally administered ${ }^{15} \mathrm{~N}$-glycine showed that the glycine nitrogen group is mainly transferred to serine $(54 \%)$, but also to urea $(20 \%)$, glutamine/glutamate $(15 \%)$, alanine $(7 \%)$, and other amino acids (leucine, isoleucine, valine, ornithine, proline, and methionine) for the remaining extent [42]. This shows that the nitrogen group from glycine or serine participates in multiple transamination reactions via glutamate formation. Using ${ }^{13} \mathrm{C}$-glycine infusion, it was observed that the flux through SHMT to ${ }^{13} \mathrm{C}$-serine was decreased in the liver of obese rats with nonalcoholic steatohepatitis (NASH) [43], thus suggesting that hepatic SHMT activity may be altered in obesity and related-metabolic disorders. To support this observation, gene expression of SHMT1 and 2 was found to be downregulated in the liver of patients with NAFLD [30].

The second main pathway of glycine utilization involves the production of $\mathrm{CO}_{2}$ and $\mathrm{NH}_{4}{ }^{+}$by the reverse reaction of the glycine synthase or glycine cleavage system mentioned above [41,44] (Figure 1). This enzymatic conversion is physiologically relevant as it provides $\mathrm{CH}_{2}-\mathrm{THF}$. $\mathrm{CH}_{2}-\mathrm{THF}$ is the major methyl group donor, through S-adenosylmethionine (SAM), for the biosynthesis of molecules such as purines, thymidylate, and methionine [41]. Exploration of the rate of glycine oxidation and urea synthesis in patients with NASH revealed no significant alterations compared to healthy individuals in the fasted state [45].

Other minor pathways include the conversion of glycine to glyoxylate by D-amino acid oxidase, to glycocyamine by the arginine:glycine amidinotransferase (AGAT), and to sarcosine by the glycine $\mathrm{N}$-methyltransferase (GNMT) [41,44]. AGAT is present in the cytosol and in the mitochondrial intermembrane space and synthesizes the precursor of creatine [46], mainly in the kidney, liver, and pancreas [47]. GNMT is localized mainly in the cytosol of periportal hepatocytes and in the exocrine pancreas. The glycine-to-sarcosine conversion requires SAM, and thus plays a key role in regulating methylation processes [5,6]. Importantly, GNMT expression is decreased both in the liver of animal models receiving a high-fat diet [48] and in patients with hepatic steatosis [49]. These alterations are further developed in Section 6.3.

\subsection{Glycine Uptake}

Together with de novo glycine synthesis, uptake of dietary glycine and re-absorption from the kidney represent the other main route for glycine bioavailability. Three classes of glycine transporters have been described: SLC36 gene family (PATs) in the intestine; SLC6 (GLYTs) in the intestine, kidney, and neural tissues; and the SLC38 family, with a wide tissue distribution [50]. The proton/amino acid transporters PAT1 and PAT2, expressed on the apical membrane of intestinal epithelial cells, mediate the symport of protons and small neutral amino acids, including glycine [50].

The sodium/chloride-dependent transporters GlyT1 and GlyT2 were first cloned from the rat brain [51,52], where glycine is an important modulator of neurotransmission [53]. GLYT1 is responsible for the high affinity transport of glycine and its derivatives, and is inhibited by sarcosine [54]. Selective GlyT-1 inhibitors increase extracellular glycine levels and potentiate N-methyl-D-aspartate (NMDA) receptor activity [55]. Hence, GLYT1 inhibition in the dorsal vagal complex suppressed hepatic glucose production, increased glucose tolerance, and reduced food intake and body weight gain in healthy, obese, and diabetic rats [56]. GLYT1 is also found throughout the intestine, where it is 
responsible for $30-50 \%$ of glycine uptake into intestinal epithelial cells across the basolateral membrane. It recently appeared to function to maintain glycine supply to enterocytes and colonocytes, mediating cytoprotection in the intestinal absorptive cells [57]. GlyT-2 has a lower affinity for glycine compared to GLYT1 [58]. It is involved in particular in maintaining terminal supplies of glycine for inhibitory glycinergic neurotransmission [59].

$\mathrm{Na}^{+}$-dependent transporters of the SLC38 family are ubiquitously expressed, and are particularly enriched in dividing cells and in cells types actively engaged in amino acid metabolism, such as hepatocytes, kidney cells, and neurons. Expression of the SLC38 transporters is polarized, being limited to plasma membrane regions facing blood vessels or engaged in cell-cell contacts, and not occurring in the apical membrane of absorptive epithelia [60].

\subsection{Glycine Conjugation and Excretion}

Recent evidence suggests that the glycine conjugation pathway is an essential detoxification pathway [61-63]. Glycine can be conjugated to various endogenous and xenobiotic metabolites (e.g., benzoate, derivatives of branched chain amino acids (BCAA), $\beta$-oxidation intermediates and metabolites of polyphenols), which can be potentially toxic when they accumulate in the organism [62]. The resulting acylglycines are less toxic and more hydrophilic and are excreted in the urine [62,64]. As these metabolites are esterified to $\mathrm{CoA}$, it has been proposed that glycine conjugation contributes to CoA homeostasis, since the reaction releases CoA [64]. Conjugation activity depends on the metabolite and on the enzyme catalyzing the reaction, i.e., acid:CoA ligases and glycine N-acyltransferases (GLYAT) [64,65].

Glycine is also involved in the enterohepatic cycle of bile acids (BAs), which are required for lipid absorption and regulation of cholesterol homeostasis [66]. These water-soluble steroids are synthesized from cholesterol exclusively in hepatocytes and include cholic acid and chenodeoxycholic acid [66]. Physiologically, most BAs are conjugated to either glycine or taurine, forming glycocholic acid and taurocholic acid, respectively [66]. In humans, glycine conjugation dominates in adulthood [67]. It is about 3.5 times higher than taurine and depends on the dietary amino acid intake [68]. Bile acid-coenzyme A: amino acid N-acyltransferase (BAAT) is the only enzyme involved in the 2 types of conjugation [67,69]. This enzyme resides in peroxisomes of hepatocytes [67,69]. After conjugation with glycine or taurine, BAs are secreted in bile and stored in the gall bladder. After food intake, BAs participates in digestion and fat absorption thanks to their detergent properties. Thereafter, BAs and associated amino acids are reabsorbed in the intestine, while the associated molecules are secreted in the feces. Obesity has been associated with increased hepatic bile acid synthesis [70] and fifty years ago, active transport of conjugated bile salts was shown to be enhanced in streptozotocin-diabetic rat small intestine [71].

\section{Plasma Concentrations of Glycine are Decreased in Obesity and Associated Metabolic Disorders, Although Dietary Intake are Unaltered}

Physiological glycine plasma concentration ranges between 200 and $300 \mu \mathrm{mol} / \mathrm{L}$. Plasma glycine levels were reported to be 9 to $13 \%$ lower in patients with NAFLD, whether obese or not, compared to controls [9]. Using the GSG (glutamate-serine-glycine) index, calculated as the ratio between the plasma level of glutamate and that of serine + glycine, this study found that the GSG index was correlated with an increased level of liver enzymes, particularly gamma-glutamyltransferase, and liver fibrosis. The study also suggested that decreased plasma glycine concentration was associated with hepatic insulin resistance. This finding is supported by a recent meta-analysis, which showed that plasma glycine concentration is consistently lower in patients with obesity and T2DM compared to healthy individuals ( -11 and $-15 \%$, respectively) [72]. Another meta-analysis showed that plasma glycine concentration has a very significant inverse association with the risk of developing T2DM [8]. In addition to these observational studies, the contribution of circulating glycine to metabolic control has been demonstrated experimentally. Using the insulin resistance homeostasis model, glycine concentrations 
were found to be positively correlated with insulin sensitivity and inversely correlated with insulin resistance [19]. Importantly, among all plasmatic amino acids analyzed individually, glycine had the highest association with alteration in insulin sensitivity, measured using a hyperinsulinemic-euglycemic clamp in 399 non-diabetic subjects presenting a broad range of insulin sensitivity [15]. The same positive association was also found in a smaller study, which used a similar approach [20]. In a consistent fashion, plasma glycine concentration was found to be lower in the lean offspring of T2DM parents compared to healthy children of control subjects [73]. On the contrary, the improvement in insulin sensitivity observed after weight loss, exercise, or medical administration of metformin was associated with improved plasma glycine concentrations in obese or T2DM subjects [74-78]. Importantly, prospective studies indicate that a decrease in plasma glycine concentration is a strong predictive factor for incident glucose intolerance and T2DM [79-81].

Similar observations have been made with two glycine precursors, i.e., betaine (trimetylglycine) $[82,83]$ and dimethylglycine [84]. Of note, plasma betaine levels are variable, ranging from 20 to $60 \mu \mathrm{M}$ in women and from 25 to $75 \mu \mathrm{M}$ in men, whereas plasma dimethylglycine levels are typically below $10 \mu \mathrm{M}$ [85]. Plasma betaine levels were lower in obese men [86] and in insulin-resistant individuals [87] as compared to healthy people. Hence, plasma betaine levels were positively correlated with insulin sensitivity [87]. In the multi-ethnic clinical trial Diabetes Prevention Program, 3234 obese or overweight individuals at high risk of developing T2DM were followed over an average of 3.2 years. In this cohort, baseline plasma betaine levels were significantly associated with incident T2DM, and any increase of betaine following a 2-year management (either through lifestyle or metformin) was associated with a lower incidence of overt T2DM [88]. Finally, in 3621 non-diabetic persons followed for an average of 7.5 years, plasma betaine was inversely correlated in a significant manner with the onset of T2DM [89].

Somehow puzzling, however, was that a reverse correlation was demonstrated with respect to sarcosine, which is an intermediate in the biosynthesis and degradation of glycine. Indeed, sarcosine plasma concentrations were increased in patients with metabolic syndrome as compared to healthy controls, and inversely correlated with the decrease in plasma glycine [90]. This may be due to alterations in metabolite urinary excretion. Indeed, in agreement with Schartum-Hansen et al. [91], Svingen et al. [89] found positive associations between the incidence of T2DM and increased urinary excretion of metabolites related to glycine metabolism, including betaine, dimethylglycine, and sarcosine.

\section{Potential Causes of Decreased Glycine Availability}

Here, we put forward the hypothesis that a decrease in glycine plasma concentrations in obesity, and secondarily in insulin resistance and T2DM, is due to a reduction of the amino acid availability resulting from the simultaneous contribution of three distinct mechanisms: (i) decreased gut absorption; (ii) decreased biosynthesis; and (iii) increased catabolism or urine excretion. We review here the potential mechanisms contributing to the establishment of glycine deficiency during the progression of metabolic disorders associated with obesity (Figure 2). 


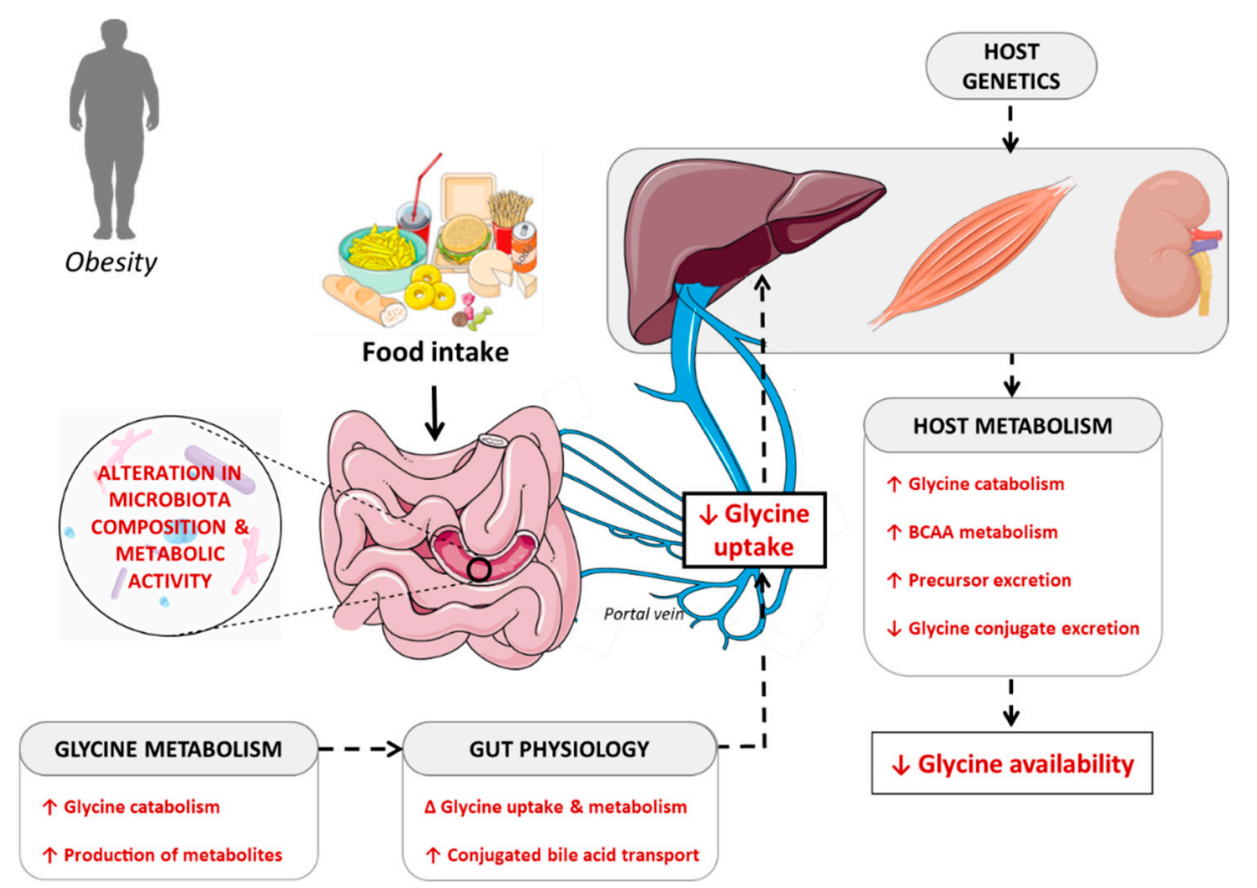

Figure 2. Potential mechanisms contributing to systemic glycine deficiency during metabolic diseases associated with obesity. Glycine dietary intake may not be the main determinant of glycine availability for the organism. Interactions between the food matrix and the intestinal microbiota influence the bacterial composition and metabolic capacity of the latter, thus modifying its ability to use glycine and produce metabolites derived from glycine. Alterations in glycine availability or microbial metabolites can modulate the expression of genes in intestinal compartments and impact the ability of the intestinal epithelium to take up glycine. Finally, interactions between the host genetics and physiology and the amount of glycine driven through the portal vein determine the fate of glycine, its bioavailability for the whole body, and its consequences on the host metabolism.

\subsection{Importance of Dietary Patterns in Determining Glycine Availability}

Based on the hypothesis that the amino acid intake determines the amino acid bioavailability and health impact, the prospective Tehran Lipid and Glucose Study examined the relationship between amino acid consumption and risk of pre-diabetes in 1878 people without T2DM, followed for an average of 5.8 years [92]. Amino acid consumption was stratified into three groups: (1) high intake of lysine, methionine, valine, aspartic acids, tyrosine, threonine, isoleucine, leucine, alanine, histidine, and serine; (2) high intake of glycine, cysteine, arginine, and tryptophan; and (3) high intake of proline and glutamic acid. Total protein consumption and high consumption of amino acids from group 1 were not associated with the development of pre-diabetes. Furthermore, high consumption of amino acids from group 2 only tended to be negatively associated with incident pre-diabetes, whereas a high consumption of amino acids from group 3 was associated with an increased risk of prediabetes [82]. This suggests that dietary intake of amino acids may selectively contribute to the risk of prediabetes (or protection thereof), depending on the amino acids being ingested.

To support this hypothesis, the multicentric EPIC study has shown that, among adult European males, the average daily intake of glycine varies little according to food choices (meat or fish eaters, vegetarians or vegans) [22]. By contrast, plasma glycine concentration was significantly altered according to food choice, being higher in the vegetarian and vegan groups compared to the meat eaters. Therefore, one can suppose that consumption of meat proteins may be associated with a low level of circulating glycine, whereas consumption of proteins from vegetable sources may be associated with higher glycine concentrations. This hypothesis, while requiring further clinical and experimental validation, is in agreement with findings from a randomized clinical trial showing that glycine concentrations after one week of a meat diet were slightly lower than those observed 
after a vegetable protein diet, even though the amount of glycine provided by the meat diet was approximately $50 \%$ higher as compared to that provided by the vegetarian diet [93]. The fact that low circulating glycine is associated to metabolic diseasesis also consistent with findings from an observational study [94] and prospective studies [95]. An investigation conducted on 2681 individuals of the sub-cohort European Prospective Investigation into Cancer and Nutrition (EPIC)-Potsdam [95] showed that total consumption of red meat was significantly associated with the risk of T2DM, after adjustment for age, sex, lifestyle, diet, and body mass index. Six plasma biomarkers, including decreased glycine, were associated with red meat consumption and risk of T2DM. Higher circulating glycine was associated with reduced risk of T2DM and was negatively correlated with red meat consumption. These results cannot, however, prove the causality of the associations. Indeed, results were not adjusted for dietary intake of glycine precursors, such as betaine, which is highly enriched in seeds, cereals, beets, and spinach. In the Complex Diseases in the Newfoundland Population: Environment and Genetics (CODING) study, betaine dietary intake in 2394 adults was the lowest in the group with the highest index of insulin resistance, and the highest in the group with the lowest index of insulin resistance [96]. Furthermore, a randomized clinical trial from Beaumont et al. [97] failed to show alterations in plasma glycine concentration in response to a 3-week dietary supplementation with casein versus soy protein in overweight humans.

To conclude, food consumption, in terms of dietary patterns, rather than dietary glycine intake, is a key determinant of glycine availability, potentially through modulation of glycine endogenous metabolic pathways.

\subsection{Contribution of the Gut Microbiota in Determining Glycine Bioavailability}

It is well-known that the liver is the main site of glycine degradation, so one could speculate that alteration in that component could be the main cause of alteration in glycine availability. However, a significant amount of glycine is also catabolized in the small intestine [10]. In young pigs, about $30 \%$ of dietary glycine is used or degraded in the small intestine by the microbiota, and is therefore not available systemically [98-100]. Indeed, glycine is highly incorporated into proteins of both gram-positive and gram-negative gut bacteria [100]. This indicates that glycine is an important amino acid for supporting the optimal growth of the gut microbiota. In patients with T2DM not treated with metformin, Forslund et al. [101] have shown that the gut microbiota was enriched in genes involved in glycine degradation. Thus, imbalances in the use of amino acids by the gut microbiota-particularly glycine-could affect the biological function of the host. However, the contribution of bacterial species from different taxa to the overall determination of glycine metabolism has not yet been studied in detail, especially in humans.

Therefore, a relevant and still unanswered question relates to the potential involvement of the gut microbiota in enhancing glycine availability for the host [102]. An interesting study showed that in rats fed with $\beta$-glucans, probiotic supplementation with Lactobacillus plantarum HEAL 9 and 19 increased portal and peripheral glycine concentrations [103]. In humans, dietary supplementation with Lactobacillus acidophilus, Bifidobacterium longum, and fructo-oligosaccharides reduced the fecal excretion of glycine [104]. Reciprocally, administration of species curbing the bioavailability of glycine has also been reported [100]; for example, introduction of Lactobacillus paracasei in the gut of germ-free mice reduced glycine concentrations in the jejunum and ileum [105]. This suggests that utilization or biosynthesis of glycine can differ between bacterial species within the gut and that pre- and probiotic dietary interventions can be used to manipulate glycine availability in the intestine, and secondarily, systemic availability. At present, however, there are too few studies available to provide unequivocal and strong support to the notion that administration of selected bacterial strains may be capable of enhancing glycine availability for the host.

Another putative action of the microbiota may occur through its capability to affect the host glycine metabolism [106]. A recent study in rats showed that the quality of the food matrix (liquid fine or gelled coarse emulsions) with similar amino acid composition alters the microbial composition in 
the ileum and caecum, and induces changes in the expression of amino acid transporters, including glycine transporters, in the ileum [107]. Therefore, the interactions between dietary proteins (and their presentation in the food matrix) and the gut microbiota can modulate the host's glycine utilization.

Finally, bacterial glycine metabolism can vary along the intestinal tract according to changes in microbiota composition and richness [108]. In the colon, amino acids are no longer absorbed, but rather are intensively metabolized by the microbiota. In that context, especially under conditions of high $\mathrm{pH}$ and low carbohydrate availability, glycine is one of the amino acids readily catabolized by colonic bacteria, thereby contributing to the synthesis of various metabolites, such as ammonia, short-chain and branched-chain fatty acids, organic acids, gaseous compounds, and amines [100]. Those microbial metabolites can impact the microbiota metabolism, the physiology of the intestinal epithelium, and the host metabolism and health. Microbial metabolites can modulate gene expression in bacteria, thus altering the expression of enzymes involved in amino acid metabolism. In addition, an elegant study using germ-free versus conventionally-raised mice demonstrated that approximately $10 \%$ of the host transcriptome is regulated by microbial agents. The concerned pathways mainly comprise genes for immunity, cell proliferation, and metabolism, and their alteration is highly localized in gut compartments [109]. Interestingly, Mardinoglu et al. [110] showed that glycine bioavailability was lower in the gut of conventionally-raised mice compared to germ-free mice and that this decrease differentially modulated the intestinal expression of genes involved in glycine synthesis and metabolism, thus reducing its bioavailability in the portal vein. This suggests that the presence of the gut microbiota reduces the bioavailability of glycine for the liver.

Overall, these data suggest that gut microbiota dysbiosis likely plays a significant role in decreasing glycine availability in obesity and associated metabolic disorders.

\subsection{Interaction between Host Metabolism and Fate of Glycine}

Hormonal regulation of glycine degradation: Glycine plasma concentration is tightly regulated by glucagon, which is a major regulator of hepatic glycine metabolism. Glucagon stimulates the activity of the glycine cleavage enzyme and the degradation of glycine [111]. Hence, glucagon deficiency is associated with a rise in circulating glycine, whereas an excess of glucagon decreases it [112]. As obesity and associated metabolic disorders are characterized by increased plasma glucagon concentration [113], this pathway could participate in increased glycine degradation [63].

Interaction with BCAA metabolism: Impaired hepatic BCAA metabolism in obesity was recently shown to significantly contribute to the decrease in glycine circulating concentration [114]. In that context, a diet restricted in BCAA restored acylglycine level in urine and increased circulating glycine level given to a rodent model of obesity [114]. White et al. [114], in Zucker fatty versus lean rats, showed that the increased circulating concentration in BCAA that results from the reduced activity of the complex branched-chain keto acid dehydrogenase (BCKDH) in the liver $[115,116]$ directly affects skeletal muscle amino acid metabolism following compensatory upregulation of BCKDH activity in that tissue. The authors elegantly showed that in obese animals, restricting BCAA dietary intake to reduce plasma BCAA levels partially to fully restored plasma and muscle glycine concentration, thus revealing a close relationship between glycine and BCAA metabolism. Yet, the underlying cellular mechanisms still remain to be fully elucidated.

Glycine urinary excretion: Decreased levels of circulating glycine could also reflect an increase in the urinary excretion of the glycine precursors betaine, dimethylglycine, and sarcosine, as observed in patients at high risk for T2DM [89,117]. This might suggest impaired tubular handling of glycine precursors. Indeed, patients at high risk for T2DM may present renal tubular dysfunction, even without overt renal impairment [118].

Host genetics and glycine metabolism: A mendelian randomization study showed a significant association between circulating levels of glycine and the single nucleotide polymorphism (SNP) rs715 in the $3^{\prime}$ untranslated region of the Carbamoyl-Phosphate Synthase 1 (CPS1) gene [119]. CPS1 is the rate-limiting enzyme for the urea cycle. It produces carbamoyl phosphate from ammonia $\left(\mathrm{NH}_{4}{ }^{+}\right)$ 
and bicarbonate $\left(\mathrm{HCO}_{3}{ }^{-}\right)$to feed the urea cycle in the mitochondria, perhaps competing with the glycine cleavage system in synthesizing glycine. Association between the SNPs rs10206976 and rs12613336 in the CPS1 gene were also pinpointed in a genome-wide association study (GWAS) [120], which suggested that individuals with a genotype leading to higher expression of CPS1 have lower levels of circulating glycine, and the opposite also holds true. Recently, meta-analysis of GWAS in 30,118 individuals of European ancestry showed four significant loci associated with circulating glycine levels [121]: two loci at the glycine cleavage system (GCS) subunits, protein P (SNP rs71503800 at GLDC, glycine decarboxylase) and protein H (SNP rs11860711 at GCSH); and two novel loci at enzymes involved in serine metabolism SNP rs478093 in PHGDH (phosphoglycerate dehydrogenase) and SNP rs6955423 in PSPH (phosphoserine phosphatase). In addition, GWAS revealed an association between the levels of betaine and the SNPs s499368 in the SLC6A12 gene (which codes for a betaine transporter) and rs17823642 near the BHMT gene [119], and between the levels of dimethylglycine and the SNP rs2431332 at the DMGDH locus (coding for dimethylglycine dehydrogenase) [84]. On the contrary, a genetic variant in $D M G D H$, causing lower DMGDH, was significantly associated with increased plasma insulin, increased HOMA index of insulin resistance, and increased risk of incident T2DM [84]. Given the paucity of available data, further studies are required to fully decipher the key steps linking alteration in the intermediate metabolism of glycine and the risks for developing metabolic disorders, such as T2DM.

\section{Potential Benefits of Glycine Supplementation in Obesity and Associated Metabolic Disorders}

Interventions that reverse or delay the onset of T2DM, such as bariatric surgery, are associated with increased glycine plasma concentrations [74-78]. In addition, acute glycine supplementation ( $5 \mathrm{~g} /$ day) was reported to improve insulin response and glucose tolerance [122,123]. Table 2 summarizes the findings of preclinical and clinical studies described in this paragraph. On a longer administration schedule ( $0.1 \mathrm{~g}$ of glycine/ $\mathrm{kg} /$ day for 14 days in association with $\mathrm{N}$-acetylcysteine), an improvement of insulin sensitivity in elderly patients with HIV was observed [124]. The health benefits of glycine supplementation were attributed to an improvement in glutathione synthesis and antioxidant protection. As a cautionary note, however, current conclusions cannot extend beyond a dose of $15 \mathrm{~g}$ of glycine per day, which is the highest dose well tolerated in adult humans [125].

Regarding the glycine precursor betaine, preclinical research showed that betaine supplementation improves insulin resistance and glucose homeostasis $[87,126]$ and reduces liver fat deposition $[34,87]$ in mice fed a high-fat diet. By contrast, a recent randomized controlled trial did not reveal major effects of betaine supplementation ( $3.30 \mathrm{~g}$ orally twice daily for 10 days, followed by $4.95 \mathrm{~g}$ twice daily for 12 weeks vs. placebo) on glucose homeostasis and liver fat deposition in patients with obesity and pre-diabetes [127]. Because betaine supplementation was associated with enhanced circulating levels of dimethylglycine, the authors suggested that betaine metabolism may be hampered by the activity of the enzyme DMGDH, which connects betaine to glycine synthesis by demethylating dimethylglycine into sarcosine. As discussed previously, allele variants at the DMGDH locus causing lower DMGDH enzyme levels were associated with insulin resistance [84].

Taken together, the above studies suggest that administration of glycine to appropriately selected patients with obesity or pre-diabetes may provide a nutritional approach to slow down the progression towards overt T2DM. However, long-term interventional studies are required to further explore the benefits of glycine supplementation in T2DM. Furthermore, the observation that glycine supplementation improves hepatic steatosis in animal models of obesity $[128,129]$ should provide a motivation for human clinical testing. 
Table 2. Summary of preclinical and clinical studies that have evaluated the health impact of glycine or betaine dietary supplementation.

\begin{tabular}{|c|c|c|c|c|}
\hline Population & Health Status & Dose and Duration & Health Impacts of Glycine Supplementation & Reference \\
\hline \multicolumn{5}{|c|}{ Glycine dietary supplementation } \\
\hline \multicolumn{5}{|c|}{ Clinical studies } \\
\hline $\begin{array}{l}\text { Adult humans: } \\
4 \text { Women } \\
5 \text { Men } \\
\text { Age: } 21 \text { to } 52 \text { y }\end{array}$ & Healthy patients & $\begin{array}{l}\text { Single oral morning dose of } 5 \mathrm{~g} \\
\text { glycine }+/-25 \mathrm{~g} \text { glucose vs. water } \\
+/-25 \mathrm{~g} \text { glucose }\end{array}$ & $\begin{array}{l}\text { Improves insulin response and glucose tolerance in response to glucose } \\
\text { ingestion }\end{array}$ & [122] \\
\hline $\begin{array}{l}\text { Adult humans: } \\
8 \text { Women } \\
4 \text { Men } \\
\text { Age: } 23.7 \pm 4.1 \mathrm{y}\end{array}$ & $\begin{array}{l}\text { Healthy lean patients with } \\
\text { first degree relatives of } \\
\text { T2DM }\end{array}$ & $\begin{array}{l}\text { Single oral morning dose of } 5 \mathrm{~g} \\
\text { glycine vs. magnesium oxide } \\
\text { (placebo) }\end{array}$ & $\begin{array}{l}\text { Improves insulin response, measured during an euglycemic-hyperinsulinemic } \\
\text { clamp; No significant alteration in insulin action }\end{array}$ & [123] \\
\hline $\begin{array}{l}\text { Adult humans: } \\
29 \text { Women } \\
23 \text { Men } \\
\text { Age: } 35 \text { to } 65 \text { y }\end{array}$ & $\begin{array}{l}\text { Patients with MetS } \\
\text { (NCEP/ATP III criteria) }\end{array}$ & $\begin{array}{l}15 \mathrm{~g} \text { glycine/day }(3 \text { times } 5 \mathrm{~g} / \mathrm{d} \text { ) } \\
\text { dissolved in water vs. starch } \\
\text { (placebo) for } 3 \text { months }\end{array}$ & $\begin{array}{l}\text { Improves systolic blood pressure in men; Protects against oxidative damages } \\
\text { determined from antioxidant enzymes activity in erythrocytes and leukocytes, } \\
\text { and thiobarbituric acid reactive substances (TBARS) in plasma }\end{array}$ & [125] \\
\hline $\begin{array}{l}\text { Elderly patients: } \\
\text { 9 Men } \\
\text { Age: } 56.1 \pm 1.0 \mathrm{y}\end{array}$ & Patients with HIV & $\begin{array}{c}1.33 \mathrm{mmol} \text { glycine } / \mathrm{kg} / \text { day with } \\
0.81 \mathrm{mmol} / \mathrm{kg} / \text { day } \mathrm{N} \text {-acetylcysteine } \\
\text { for } 14 \text { days }\end{array}$ & $\begin{array}{l}\text { Improves insulin sensitivity, measured by hyperinsulinemic-euglycemic clamp } \\
\text { before and after supplementation }\end{array}$ & [124] \\
\hline \multicolumn{5}{|c|}{ Preclinical studies } \\
\hline $\begin{array}{l}\text { Male Sprague Dawley } \\
\text { rats: } n=48 \\
\text { Age: } N A\end{array}$ & $\begin{array}{l}\text { High fat/high sucrose } \\
\text { feeding vs. standard chow } \\
\text { for } 24 \text { weeks }\end{array}$ & $\begin{array}{l}3.5 \mathrm{~g} \text { glycine } / \mathrm{kg} / \mathrm{day} \text { in water vs. } \\
\text { water (placebo) for } 24 \text { weeks }\end{array}$ & Improves hepatic steatosis assessed histologically & [128] \\
\hline $\begin{array}{l}\text { Male KK-Ay mice: } \\
n=5 / \text { group } \\
\text { Age: } 7 \text { weeks }\end{array}$ & $\begin{array}{l}\text { Animal model of obesity } \\
\text { and T2DM }\end{array}$ & $\begin{array}{l}\text { Semisynthetic diet containing } 5 \% \\
\text { glycine vs. casein (placebo) for } \\
\quad 4 \text { weeks }\end{array}$ & $\begin{array}{l}\text { Improves hepatic steatosis assessed histologically Improves glucose tolerance } \\
\text { measured during a glucose tolerance test }\end{array}$ & [129] \\
\hline \multicolumn{5}{|c|}{ Betaine dietary supplementation } \\
\hline \multicolumn{5}{|c|}{ Clinical studies } \\
\hline $\begin{array}{l}\text { Adult humans: } \\
8 \text { Women } \\
20 \text { Men } \\
\text { Age: } 21 \text { to } 70 \mathrm{y}\end{array}$ & $\begin{array}{l}\text { patients with obesity and } \\
\text { pre-diabetes }\end{array}$ & $\begin{array}{l}3.30 \mathrm{~g} \text { betaine, twice daily for } 10 \\
\text { days, followed by } 4.95 \mathrm{~g} \text { twice daily } \\
\text { for } 12 \text { weeks vs. microcrystalline } \\
\text { cellulose (placebo) }\end{array}$ & $\begin{array}{l}\text { No major effects on glucose homeostasis (euglycemic hyperinsulinemic clamp) } \\
\text { and liver fat deposition }\end{array}$ & [127] \\
\hline
\end{tabular}


Table 2. Cont.

\begin{tabular}{|c|c|c|c|c|}
\hline Population & Health Status & Dose and Duration & Health Impacts of Glycine Supplementation & Reference \\
\hline \multicolumn{5}{|c|}{ Preclinical studies } \\
\hline $\begin{array}{l}\text { Female } \\
\text { Kunming } \\
\text { Mice: } n=40 \\
\text { Age: } 6 \text { weeks }\end{array}$ & $\begin{array}{l}\text { High-fat feeding for } \\
13 \text { weeks }\end{array}$ & $\begin{array}{l}1 \% \text { weight } / \text { volume betaine, in water } \\
\text { vs. water for } 1 \text { week }\end{array}$ & $\begin{array}{l}\text { Improves insulin resistance and glucose homeostasis measured using } \\
\text { glucose/insulin tolerance tests }\end{array}$ & [126] \\
\hline $\begin{array}{l}\text { Male C57Bl6 mice: } \\
n=24 \\
\text { Age: } N A\end{array}$ & $\begin{array}{l}\text { High-fat feeding for } \\
16 \text { weeks }\end{array}$ & $\begin{array}{l}1 \% \text { weight } / \text { volume betaine, in water } \\
\text { vs. water for } 1 \text { week }\end{array}$ & $\begin{array}{l}\text { Improves insulin resistance and glucose homeostasis measured using } \\
\text { glucose/insulin tolerance test and euglycemic hyperinsulinemic clamp; } \\
\text { Reduces liver fat deposition quantified on chloroform-methanol extracts }\end{array}$ & [87] \\
\hline $\begin{array}{l}\text { Male C57BL6/N mice: } \\
n=46 \\
\text { Age: } 8 \text { weeks }\end{array}$ & $\begin{array}{l}\text { High-fat feeding for } 12 \\
\text { weeks, methyl-donor } \\
\text { supplementation was given } \\
\text { during the last } 4 \text { weeks }\end{array}$ & $\begin{array}{c}15 \mathrm{~g} / \mathrm{kg} \text { betaine, } 15 \mathrm{~g} / \mathrm{kg} \text { choline } \\
\text { chloride, } 7.5 \mathrm{~g} / \mathrm{kg} \text { methionine, } 15 \\
\mathrm{mg} / \mathrm{kg} \text { folic acid, } 1.5 \mathrm{mg} / \mathrm{kg} \text { vitamin } \\
\text { B12, } 150 \mathrm{mg} / \mathrm{kg} \mathrm{ZnSO} 4\end{array}$ & $\begin{array}{l}\text { Prevented the progression of hepatic steatosis Increases phosphorylation of } \\
\text { AMPK- } \alpha \text { together with enhanced } \beta \text {-HAD activity, suggesting increased fatty } \\
\text { acid oxidation }\end{array}$ & [34] \\
\hline
\end{tabular}

Note: MetS = Metabolic syndrome; T2DM = type 2 diabetes; NA = not available . 


\section{The Contribution of Glycine to Host Metabolism and the Pathogenesis of Metabolic Disorders}

\subsection{Importance of Glycine for Antioxidant Protection by Glutathione}

Glycine participates in many biological functions, since it is necessary for the synthesis of glutathione, purines, creatine, porphyrins of heme, and primary bile salts. Theoretical calculations have estimated that glutathione synthesis represents approximately $38 \%$ of the glycine flux necessary for the synthesis of the metabolites mentioned above; this flow amounts to approximately $1.5 \mathrm{~g}$ of glycine/day [4]. In comparison, Meléndez-Hevia et al. [4] estimated that $12 \mathrm{~g} /$ day of glycine is needed for collagen synthesis and $1 \mathrm{~g} /$ day for the synthesis of other proteins in the body.

It was suggested that glycine availability may be the limiting factor for glutathione synthesis (Figure 3) [130]. Indeed, the tissue glycine concentration is lower than the Michael constant (Km) of glutathione synthase. Thus, in some situations, the availability of glycine may be too low to maintain an adequate synthesis rate of glutathione, especially in metabolic diseases characterized by enhanced oxidative stress [131]. This is associated with an increase in tissue levels of $\gamma$-glutamylcysteine, which is converted by the $\gamma$-glutamyl cyclotransferase to cysteine and 5-oxoproline, the latter metabolite being excreted in the urine.

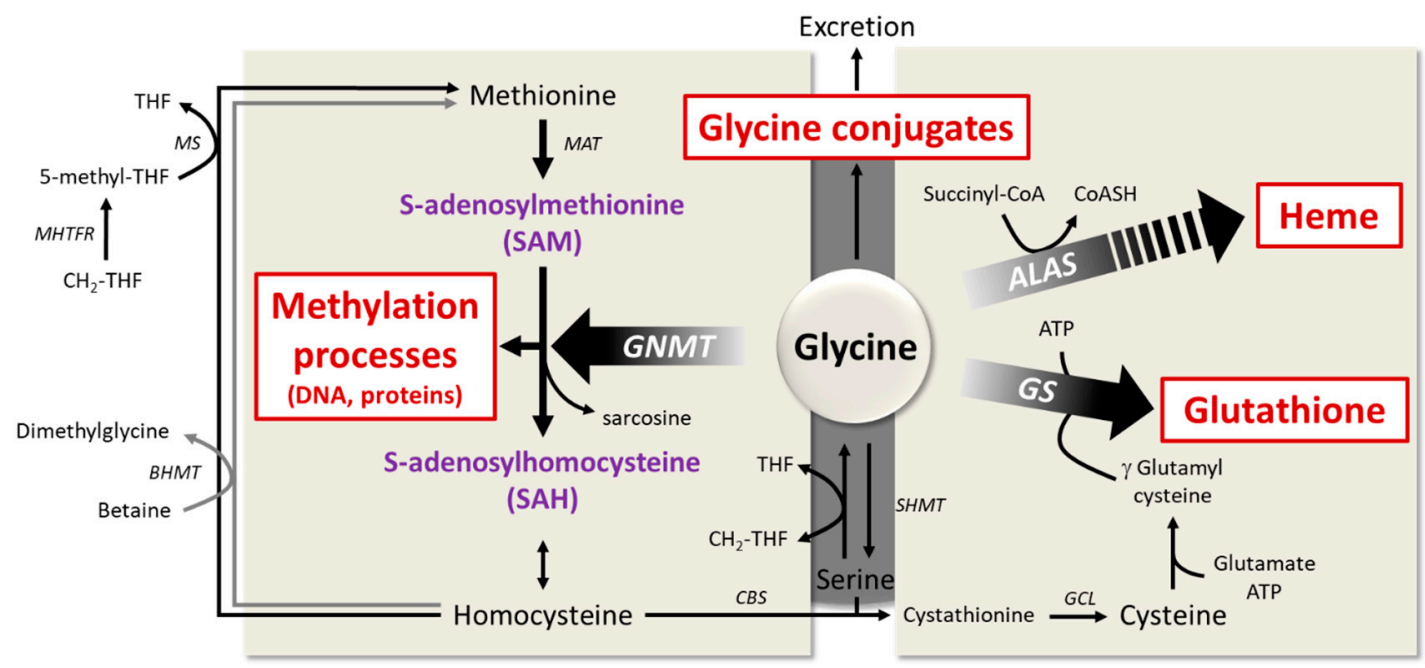

Figure 3. Main pathways involving glycine in host metabolism. Note: ALAS = delta-aminolevulinic acid synthase; BHMT = betaine-homocysteine S-methyltransferase; CBS = cystathionine $\beta$-synthase; CGL = cystathionine $\gamma$-lyase; GNMT = glycine N-methyltransferase; GCL = glutamate-cysteine ligase; GS = glutathione synthase; MAT = methionine adenosyltransferase; $\mathrm{MS}=$ methionine synthase; $\mathrm{SAM}=$ S-adenosylmethionine; $\mathrm{SAH}=\mathrm{S}$-adenosylhomocysteine; $\mathrm{SDH}=$ sarcosine dehydrogenase; SHMT = serine hydroxymethyltransferase; THF = tetrahydrofolate; $\mathrm{CH}_{2}-\mathrm{THF}=\mathrm{N}^{5}, \mathrm{~N}^{10}$-methylene tetrahydrofolate; 5-methyl-THF = 5-methyltetrahydrofolate.

Several metabolic studies have suggested that glycine may play a role in insulin resistance and T2DM through alteration in glutathione synthesis rate. Glutathione concentration was $60 \%$ lower in erythrocytes of patients with T2DM compared to controls [132]. This was notably associated with a 50\% lower absolute synthesis rate of glutathione [132,133]. Limited availability of glycine may play a key role in that alteration, since dietary supplementation with glycine is able to increase the glutathione levels in tissues of several animal models and in humans [124,134]. For instance, glycine supplementation $(0.1 \mathrm{~g} / \mathrm{kg} /$ day $)$ for 14 days in association with $\mathrm{N}$-acetylcysteine overcame the deficiency in glutathione synthesis in patients with T2DM [134] and in elderly HIV-infected patients [124]. In an in vitro setting, improving the transport of glycine in diabetic $\beta$-cells has been shown to increase glutathione synthesis and protect against oxidative stress [135]. Finally, a modeling approach in 86 patients with varying degrees of hepatic steatosis pointed out a causative involvement of reduced 
de novo glutathione synthesis in NAFLD, which was in part overcome after supplementation of glutathione precursors [32].

\subsection{The Role of Glycine in Heme Biosynthesis}

In mammalians, heme production requires three substrates and a multistep biosynthetic pathway involving eight enzymes. The first and rate-controlling reaction of heme biosynthesis is the mitochondrial formation, catalyzed by ALA synthase, of delta-aminolevulinic acid (ALA) from succinyl CoA, generated within the tricarboxylic acid cycle, and glycine [136].

The biosynthesis of one heme molecule requires eight molecules of glycine and one iron atom, and an inadequate supply of glycine to erythroid cells, the lineage in which heme biosynthesis is predominant, leads to a decreased production of heme. Genetic disruption of GLYT1, a glycine transporter 1 in mice, yielded very early postnatal death (1-day old) due to the development of a microcytic anemia [137]. The finding that Glyt1-deficiency causes a lethal phenotype further supports the notion that glycine uptake is necessary, and glycine endogenous production is insufficient, in cell types requiring high amounts of the amino acid [137].

Importantly, heme biosynthesis is crucial for ensuring mitochondrial protein stability and function, such as complex I and III of the electron transfer chain [138]. Decreased heme content could participate in mitochondrial dysfunction and reduced respiratory activity [138].

\subsection{Importance of Glycine Conjugation and Urinary Excretion}

As discussed above, glycine is important for detoxification of certain intermediaries accumulated in excess. This is particularly crucial in obesity and associated metabolic disorders, as synergistic alterations in fatty acid and BCAA metabolism have been reported to raise production of acyl groups $[78,139]$. Urinary metabolomics profiling revealed lower urinary excretion of acylglycines in patients with obesity compared to lean individuals [140], as well as in diet-induced obese mice compared to lean animals [141]. In addition, improving insulin sensitivity via physical exercise in patients with obesity [140] or by administration of a BCAA restricted diet in diet-induced obese mice [114] increases several glycine conjugates in the urine. This suggests that the glycine conjugation processes may be less efficient in obesity and associated metabolic disorders. Yet, the impact of glycine supplementation on these processes still remains to be investigated.

\subsection{The Key Role of Glycine in the One-Carbon Metabolism}

Glycine metabolism is a key regulator of methyl donors. In the liver, it participates in the regulation of the ratio between S-adenosylmethionine (SAM) and S-adenosylhomocysteine (SAH), as it is the substrate for the enzyme glycine-N-methyltransferase (GNMT) [26,142]. The main biological role of GNMT is to regulate the level of SAM, as it uses SAM and glycine to produce sarcosine. Since SAM is involved in methyl group transfer necessary for many biological processes and maintenance of the genetic stability $[5,6]$, the regulation of GNMT activity is essential for metabolic homeostasis. In addition, GNMT promotes homocysteine re-methylation by the folate-dependent enzyme, methionine synthase, by increasing hepatic content in 5-methyl-THF [143].

GNMT activity is inhibited by 5-methyl-THF produced from $\mathrm{CH} 2-\mathrm{THF}$ reductase [144]. Thus, folate deficiency induces GNMT activity, whereas choline and methionine deficiency inhibits it (Figure 3). GNMT activity is also regulated at the transcriptional level [145]. It is worth noting that over 4 decades ago, GNMT expression was shown to be increased in ageing animals [142]. By contrast, decreased GNMT expression is observed in NAFLDs, both in animal models receiving a high-fat diet [48] and in patients with hepatic steatosis [49]. Furthermore, DNA hypermethylation represses GNMT gene expression in the pathogenesis of NAFLD [146] and hepatocellular carcinoma [145,147]. The loss of GNMT in hepatocellular carcinoma may favor the appearance of aberrant DNA methylation patterns on some promoters [145]. Hence, in $\mathrm{Gnmt}^{-/}$mice [148,149], hepatic concentrations of methionine and SAM and the ratio of SAM/SAH were multiplied by 7,36 , and 100, respectively, 
as compared to wild-type animals, suggesting a significant increase in various cellular methylation reactions. Older $\mathrm{Gnmt}^{-/-}$mice develop hepatocellular carcinoma associated with hypermethylation of RASSF1 (Ras association domain family member 1) and SOCS2 (suppressor of cytokine signaling 2) promoters, and silencing of the respective genes. Those two proteins act to inhibit the Ras and JAK/STAT signaling pathways, which are involved in cell proliferation and tumor formation [6].

$\mathrm{Gnmt}^{-/-}$mice, particularly females, also exhibit glucose intolerance and insulin resistance compared to wild-type animals [150]. Very interestingly, a recent study showed that the absence of GNMT causes metabolic reprogramming, whereby nutrients are channeled from glucose formation to pathways that demand high SAM concentration, namely polyamine synthesis and catabolism, trans-sulfuration, and de novo lipogenesis. As a consequence, GNMT mice ${ }^{-/-}$are characterized by reduced gluconeogenesis due to a decrease in precursors, and hepatic steatosis due to enhanced citrate availability [151].

\subsection{Glycine as a Neurotransmitter}

Glycine is involved in regulating the systemic level of amino acids used as neurotransmitters, whose accumulation in the central nervous system could be neurotoxic [62]. It is a glycine receptor agonist (GlyRs) [152] and an antagonist of the NMDA receptor [153] in the central nervous system. Structure and function of these receptors are reviewed in previous studies [12,63]. In vivo activation of the NMDA receptor by glycine in the dorsal vagal complex was shown to decrease hepatic glucose production, while inhibition of the receptor and hepatic vagotomy neutralized this effect [154]. Furthermore, activation of the NMDA receptor has been involved in controlling food intake, its inhibition leading to an increase in food intake [155]. In another respect, mice fed a high-fat diet were shown to exhibit an increased expression of GlyRs in the hypothalamus, suggesting that the receptor is involved in the central regulation of orexigenic signals in obesity [156].

GlyRs are also expressed in peripheral, non-neuronal tissues and immune cells [12,63]. First, glycine is a well-known secretagogue of key hormones in glucose homeostasis, i.e., GLP-1 [157], insulin, and glucagon $[122,123,126]$. Explorations on islets of human donors showed that $\beta$-cells express the receptor GlyR, especially the GlyR $\alpha 1$ subunit, and the glycine transporters GlyT1 and GlyT2 [158]. GlyR activation by glycine promotes membrane depolarization and insulin secretion in islets of donors without T2DM. The decrease in GlyR expression in $\beta$-cells of donors with T2DM has been associated with a disruption of glycine-induced insulin secretion [158]. Second, in macrophages, lymphocyte $\mathrm{T}$, and neutrophils, GlyR activation suppresses the production of pro-inflammatory cytokines by hyperpolarizing the immune cells, thus supporting anti-inflammatory properties [159].

\section{Conclusions}

Glycine is now recognized as a relevant plasma marker for metabolic diseases associated with obesity. It is, thus, considered a promising amino acid for improving metabolic health. However, it is still unclear whether the decline in glycine levels is causatively involved in the pathogenesis of metabolic disorders, particularly glucose intolerance, insulin resistance, and T2DM. Overall, the literature suggests that the key metabolic pathways of glycine can be differentially altered according to metabolic disorders (Figure 4). For example, GNMT deficiency is well described in NAFLD but not in T2DM. Understanding the differences and similarities between T2DM and NAFLD in relation to glycine metabolism will be of the greatest interest to improve our understanding of the relationship between the two pathologies. Likewise, it will be extremely relevant to decipher the role of glycine metabolism in cancers, in which glycine metabolism is also fundamental, not least to govern the methylation status of cancer cells [160,161]. 


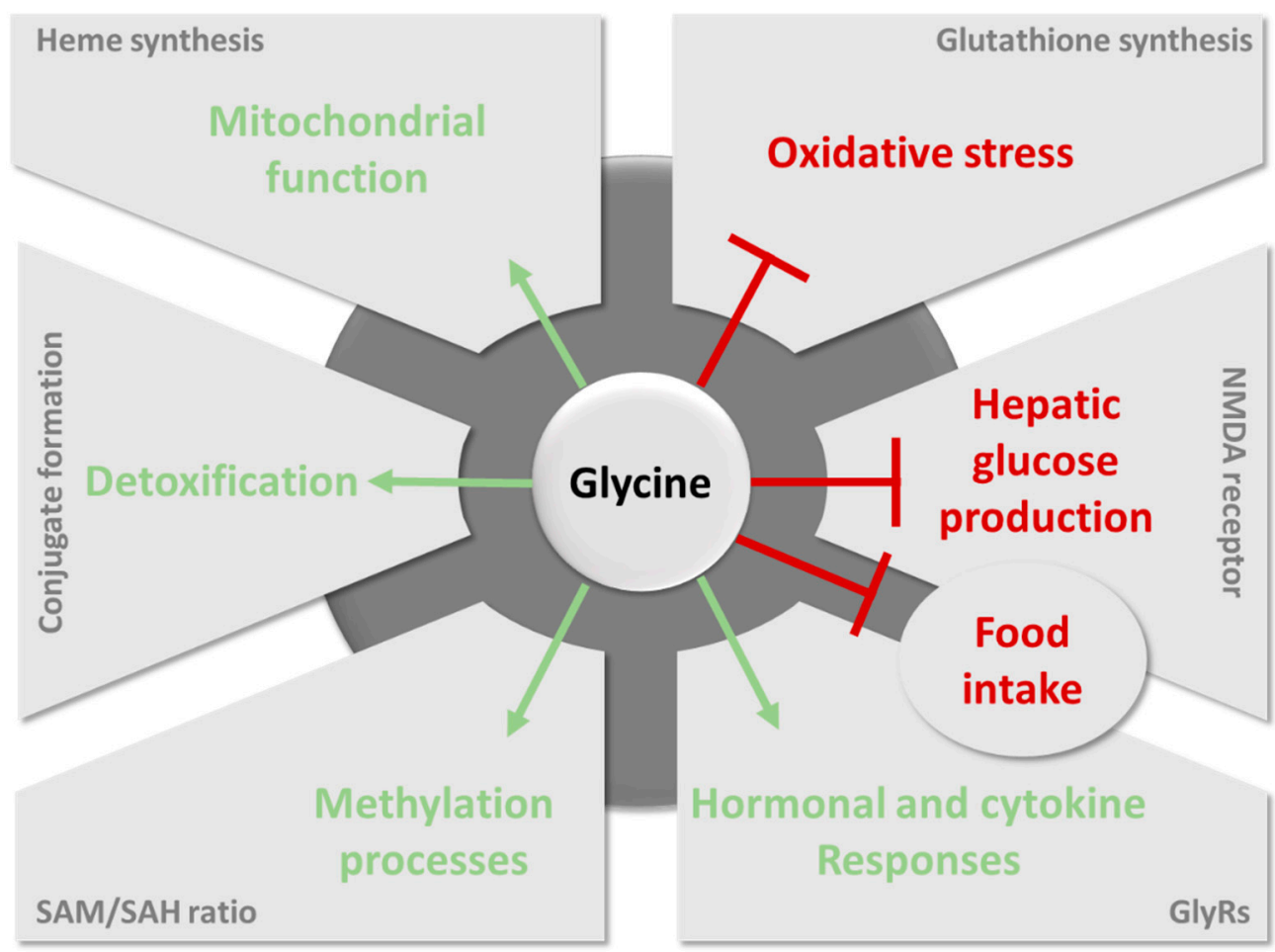

Figure 4. Main pathways involving glycine in health benefits. Metabolic benefits mediated by glycine include the inhibition of oxidative stress via increased glutathione biosynthesis, an inhibitory effect on gluconeogenesis and food intake via activation of the NMDA receptor, curbing the overload. Glycine also exerts positive effects on mitochondrial activity via heme biosynthesis, detoxification processes via urinary excretion of glycine conjugates, and regulation of hormonal (enhanced secretion of key hormones in glucose homeostasis) and cytokine (reduced production of pro-inflammatory cytokines) responses via activation of GlyRs. Finally, glycine impinges the SAM biosynthetic process, decreasing the availability of methyl-donors, and thus regulating methylation. Favorable pathways induced by glycine are green; the harmful pathways inhibited by glycine are red. Note: NMDA = N-methyl-D-aspartate; GlyRs = glycine receptors; SAM = S-adenosylmethionine; SAH = S-adenosylhomocysteine.

If the benefit of glycine for improving metabolic health is confirmed, the mechanisms underlying the long-term effects of glycine supplementation will need to be fully understood. Doses and modes of administration of the amino acid will have to be determined in phase I dose escalation studies to ensure the efficacy and safety of dietary supplementation and clinical treatment. In that context, as the importance of the gut microbiota in determining the availability of glycine becomes more obvious, promising prospects are expected in the development of pre- and probiotics quantitatively affecting glycine bioavailability to the host.

Funding: This research received no external funding.

Conflicts of Interest: The authors do not have any conflict of interest to declare.

\section{Abbreviations}

AGAT

ALA

ALAS

BA

BAAT

BCAA

$\mathrm{BCKDH}$

BHMT
Alanine:glyoxylate aminotransferase

delta-aminolevulinic acid

delta-aminolevulinic acid synthase

Bile acids

Bile acid-coenzyme A: amino acid $\mathrm{N}$-acyltransferase

Branched chain amino acids

Branched-chain keto acid dehydrogenase

Betaine-homocysteine S-methyltransferase 


$\begin{array}{ll}\text { CH2-THF } & \text { 5,10-methylene tetrahydrofolate } \\ \text { CPS1 } & \text { Carbamoyl-Phosphate Synthase 1 } \\ \text { DHF } & \text { dihydrofolate } \\ \text { DHFR } & \text { dihydrofolate reductase } \\ \text { DMGDH } & \text { Dimethylglycine dehydrogenase } \\ \text { EPIC } & \text { European Prospective Investigation into Cancer and Nutrition } \\ \text { GLYAT } & \text { Glycine N-acyltransferases } \\ \text { GlyR } & \text { Glycine receptor } \\ \text { GNMT } & \text { Glycine N-methyltransferase } \\ \text { GSG index } & \text { Glutamate-serine-glycine index } \\ \text { GWAS } & \text { Genome-wide association study } \\ \text { HOMA index } & \text { Homeostatic Model Assessment index } \\ \text { NAFLD } & \text { Non-alcoholic fatty liver disease } \\ \text { NMDA } & \text { N-methyl-D-aspartate } \\ \text { SAM } & \text { S-adenosylmethionine } \\ \text { SAH } & \text { S-adenosylhomocysteine } \\ \text { SDH } & \text { Sarcosine dehydrogenase (SDH) } \\ \text { SHMT } & \text { Serine hydroxymethyltransferase } \\ \text { SNP } & \text { Single nucleotide polymorphism } \\ \text { T2DM } & \text { Type 2 diabetes mellitus } \\ \text { THF } & \text { tetrahydrofolate }\end{array}$

\section{References}

1. Jackson, A.A.; Badaloo, A.V.; Forrester, T.; Hibbert, J.M.; Persaud, C. Urinary excretion of 5-oxoproline (pyroglutamic aciduria) as an index of glycine insufficiency in normal man. Br. J. Nutr. 1987, 58, 207-214. [CrossRef] [PubMed]

2. Gersovitz, M.; Bier, D.; Matthews, D.; Udall, J.; Munro, H.N.; Young, V.R. Dynamic aspects of whole body glycine metabolism: Influence of protein intake in young adult and elderly males. Metabolism 1980, 29, 1087-1094. [CrossRef]

3. Yu, Y.M.; Yang, R.D.; Matthews, D.E.; Wen, Z.M.; Burke, J.F.; Bier, D.L.; Young, V.R. Quantitative aspects of glycine and alanine nitrogen metabolism in postabsorptive young men: Effects of level of nitrogen and dispensable amino acid intake. J. Nutr. 1985, 115, 399-410. [CrossRef]

4. Meléndez-Hevia, E.; De Paz-Lugo, P.; Cornish-Bowden, A.; Cárdenas, M.L. A weak link in metabolism: The metabolic capacity for glycine biosynthesis does not satisfy the need for collagen synthesis. J. Biosci. 2009, 34, 853-872. [CrossRef] [PubMed]

5. Luka, Z.; Cerone, R.; Phillips, J.A., 3rd; Mudd, H.S.; Wagner, C. Mutations in human glycine $\mathrm{N}$-methyltransferase give insights into its role in methionine metabolism. Hum Genet. 2002, 110, 68-74. [CrossRef]

6. Martínez-Chantar, M.L.; Vázquez-Chantada, M.; Ariz, U.; Martínez, N.; Varela, M.; Luka, Z.; Capdevila, A.; Rodríguez, J.; Aransay, A.M.; Matthiesen, R.; et al. Loss of the glycine N-methyltransferase gene leads to steatosis and hepatocellular carcinoma in mice. Hepatology 2008, 47, 1191-1199. [CrossRef] [PubMed]

7. Durkin, P.J.; Friedberg, F. The synthesis of glutathione in torula utilis studied with 14C-carboxyl labeled glycine. Biochim. Biophys. Acta 1952, 9, 105-106. [CrossRef]

8. Guasch-Ferre, M.; Hruby, A.; Toledo, E.; Clish, C.B.; Martınez-Gonzalez, M.A.; Salas-Salvado, J.; Hu, F.B. Metabolomics in prediabetes and diabetes: A systematic review and meta-analysis. Diabetes Care 2016, 39, 833-846. [CrossRef]

9. Gaggini, M.; Carli, F.; Rosso, C.; Buzzigoli, E.; Marietti, M.; Della Latta, V.; Ciociaro, D.; Abate, M.L.; Gambino, R.; Cassader, M.; et al. Altered amino acid concentrations in NAFLD: Impact of obesity and insulin resistance. Hepatology 2018, 67, 145-158. [CrossRef]

10. Wang, W.; Wu, Z.; Dai, Z.; Yang, Y.; Wang, J.; Wu, G. Glycine metabolism in animals and humans: Implications for nutrition and health. Amino Acids 2013, 45, 463-477. [CrossRef] 
11. Adeva-Andany, M.; Souto-Adeva, G.; Ameneiros-Rodríguez, E.; Fernández-Fernández, C.; Donapetry-García, C.; Domínguez-Montero, A. Insulin resistance and glycine metabolism in humans. Amino Acids 2018, 50, 11-27. [CrossRef] [PubMed]

12. Pérez-Torres, I.; Zuniga-Munoz, A.M.; Guarner-Lans, V. Beneficial effects of the amino acid glycine. Mini-Rev. Med. Chem. 2017, 17, 15-32. [CrossRef] [PubMed]

13. Razak, M.A.; Begum, P.S.; Viswanath, B.; Rajagopal, S. Multifarious beneficial effect of nonessential amino acid, glycine: A review. Oxid. Med. Cell. Longev. 2017, 2017, 1716701. [CrossRef] [PubMed]

14. Gar, C.; Rottenkolber, M.; Prehn, C.; Adamski, J.; Seissler, J.; Lechner, A. Serum and plasma amino acids as markers of prediabetes, insulin resistance, and incident diabetes. Crit. Rev. Clin. Lab. Sci. 2018, 55, 21-32. [CrossRef] [PubMed]

15. Gall, W.E.; Beebe, K.; Lawton, K.A.; Adam, K.P.; Mitchell, M.W.; Nakhle, P.J.; Ryals, J.A.; Milburn, M.V.; Nannipieri, M.; Camastra, S.; et al. $\alpha$-hydroxybutyrate is an early biomarker of insulin resistance and glucose intolerance in a nondiabetic population. PLoS ONE 2010, 5, e10883. [CrossRef] [PubMed]

16. Thalacker-Mercer, A.E.; Ingram, K.H.; Guo, F.; Ilkayeva, O.; Newgard, C.B.; Garvey, W.T. BMI, RQ, diabetes, and sex affect the relationships between amino acids and clamp measures of insulin action in humans. Diabetes 2014, 63, 791-800. [CrossRef]

17. Tulipani, S.; Palau-Rodriguez, M.; Miñarro Alonso, A.; Cardona, F.; Marco-Ramell, A.; Zonja, B.; Lopez de Alda, M.; Muñoz-Garach, A.; Sanchez-Pla, A.; Tinahones, F.J.; et al. Biomarkers of Morbid Obesity and Prediabetes by Metabolomic Profiling of Human Discordant Phenotypes. Clin. Chim. Acta 2016, 463, 53-61. [CrossRef]

18. Cheng, S.; Rhee, E.P.; Larson, M.G.; Lewis, G.D.; McCabe, E.L.; Shen, D.; Palma, M.L.; Roberts, L.D.; Dejam, A.; Souza, A.L.; et al. Metabolite profiling identifies pathways associated with metabolic risk in humans. Circulation 2012, 125, 2222-2231. [CrossRef]

19. Takashina, C.; Tsujino, I.; Watanabe, T.; Sakaue, S.; Ikeda, D.; Yamada, A.; Sato, T.; Ohira, H.; Otsuka, Y.; Oyama-Manabe, N.; et al. Associations among the plasma amino acid profile, obesity, and glucose metabolism in Japanese adults with normal glucose tolerance. Nutr. Metab. (Lond.) 2016, 13, 5. [CrossRef]

20. Labonte, C.C.; Farsijani, S.; Marliss, E.B.; Bougeon, R.; Morais, J.A.; Pereira, S.; Bassil, M.; Winter, A.; Murphy, J.; Combs, T.P.; et al. Plasma Amino Acids vs Conventional Predictors of Insulin Resistance Measured by the Hyperinsulinemic Clamp. J. Endocr. Soc. 2017, 1, 861-873. [CrossRef]

21. US Department of Agriculture, Agricultural Research Service, Nutrient Data Laboratory. USDA National Nutrient Database for Standard Reference, Release 28. Version Current: September 2015. Internet: /nea/bhnrc/ndl.

22. Schmidt, J.A.; Rinaldi, S.; Scalbert, A.; Ferrari, P.; Achaintre, D.; Gunter, M.J.; Appleby, P.N.; Key, T.J.; Travis, R.C. Plasma concentrations and intakes of amino acids in male meat-eaters, fish-eaters, vegetarians and vegans: A cross-sectional analysis in the EPIC-Oxford cohort. Eur. J. Clin. Nutr. 2016, 70, 306-312. [CrossRef] [PubMed]

23. Lamers, Y.; Williamson, J.; Gilbert, L.R.; Stacpoole, P.W.; Gregory, J.F., 3rd. Glycine turnover and decarboxylation rate quantified in healthy men and women using primed, constant infusions of [1,2-(13)C2]glycine and [(2)H3]leucine. J. Nutr. 2007, 137, 2647-2652. [CrossRef] [PubMed]

24. Robert, J.J.; Bier, D.M.; Zhao, X.H.; Matthews, D.E.; Young, V.R. Glucose and insulin effects on the novo amino acid synthesis in young men: Studies with stable isotope labeled alanine, glycine, leucine, and lysine. Metabolism 1982, 31, 1210-1218. [CrossRef]

25. Robert, J.J.; Beaufrere, B.; Koziet, J.; Desjeux, J.F.; Bier, D.M.; Young, V.R.; Lestradet, H. Whole body de novo amino acid synthesis in type I (insulin-dependent) diabetes studied with stable isotope-labeled leucine, alanine, and glycine. Diabetes 1985, 34, 67-73. [CrossRef] [PubMed]

26. Ducker, G.S.; Rabinowitz, J.D. One-carbon metabolism in health and disease. Cell Metab. 2017, $25,27-42$. [CrossRef] [PubMed]

27. Garrow, T.A.; Brenner, A.A.; Whitehead, V.M.; Chen, X.N.; Duncan, R.G.; Korenberg, J.R.; Shane, B. Cloning of human cDNAs encoding mitochondrial and cytosolic serine hydroxymethyltransferases and chromosomal localization. J. Biol. Chem. 1993, 268, 11910-11916. [PubMed]

28. Pfendner, W.; Pizer, L.I. The metabolism of serine and glycine in mutant lines of Chinese hamster ovary cells. Arch. Biochem. Biophys. 1980, 200, 503-512. [CrossRef] 
29. Melendez-Hevia, E.; Paz-Lugo, P.D. Branch-point stoichiometry can generate weak links in metabolism: The case of glycine biosynthesis. J. Biosci. 2008, 33, 771-780. [CrossRef]

30. Mardinoglu, A.; Agren, R.; Kampf, C.; Asplund, A.; Uhlen, M.; Nielsen, J. Genome-scale metabolic modelling of hepatocytes reveals serine deficiency in patients with non-alcoholic fatty liver disease. Nat. Commun. 2014, 5, 3083. [CrossRef]

31. Lewis, R.M.; Godfrey, K.M.; Jackson, A.A.; Cameron, I.T.; Hanson, M.A. Low serine hydroxymethyltransferase activity in the human placenta has important implications for fetal glycine supply. J. Clin. Endocrinol. Metab. 2005, 90, 1594-1598. [CrossRef]

32. Mardinoglu, A.; Bjornson, E.; Zhang, C.; Klevstig, M.; Söderlund, S.; Ståhlman, M.; Adiels, M.; Hakkarainen, A.; Lundbom, N.; Kilicarslan, M.; et al. Personal model-assisted identification of NAD(+)and glutathione metabolism as intervention target in NAFLD. Mol. Syst. Biol. 2017, 13, 916. [CrossRef] [PubMed]

33. Soloway, S.; Stetten, D., Jr. The metabolism of choline and its conversion to glycine in the rat. J. Biol. Chem. 1953, 204, 207-214. [PubMed]

34. Ahlhoff, C.; Worsch, S.; Sailer, M.; Hummel, B.A.; Fiamoncini, J.; Uebel, K.; Obeid, R.; Scherling, C.; Geisel, J.; Bader, B.L.; et al. Methyl-donor supplementation in obese mice prevents the progression of NAFLD, activates AMPK and decreases acyl-carnitine levels. Mol. Metab. 2014, 3, 565-580. [CrossRef] [PubMed]

35. Dahlhoff, C.; Desmarchelier, C.; Sailer, M.; Fürst, R.W.; Haag, A.; Ulbrich, S.E.; Hummel, B.; Obeid, R.; Geisel, J.; Bader, B.L.; et al. Hepatic methionine homeostasis is conserved in C57BL/6N mice on high-fat diet despite major changes in hepatic one-carbon metabolism. PLoS ONE 2013, 8, e57387. [CrossRef]

36. Holmes, R.P.; Assimos, D.G. Glyoxylate synthesis, and its modulation and influence on oxalate synthesis. J. Urol. 1998, 160, 1617-1624. [CrossRef]

37. Eastman, H.B.; Swick, A.G.; Schmitt, M.C.; Azizkhan, J.C. Stimulation of dihydrofolate reductase promoter activity by antimetabolic drugs. Proc. Natl. Acad. Sci. USA 1991, 88, 8572-8576. [CrossRef] [PubMed]

38. Urlaub, G.; Chasin, L.A. Isolation of Chinese hamster cell mutants deficient in dihydrofolate reductase activity. Proc. Natl. Acad. Sci. USA 1980, 77, 4216-4220. [CrossRef]

39. Meierhofer, D.; Weidner, C.; Sauer, S. Integrative analysis of transcriptomics, proteomics, and metabolomics data of white adipose and liver tissue of high-fat diet and rosiglitazone-treated insulin-resistant mice identified pathway alterations and molecular hubs. J. Proteome Res. 2014, 13, 5592-5602. [CrossRef]

40. Yamamoto, E.; Nakamura, T.; Kataoka, K.; Tokutomi, Y.; Dong, Y.F.; Fukuda, M.; Nako, H.; Yasuda, O.; Ogawa, H.; Kim-Mitsuyama, S. Nifedipine prevents vascular endothelial dysfunction in a mouse model of obesity and type 2 diabetes, by improving eNOS dysfunction and dephosphorylation. Biochem. Biophys. Res. Commun. 2010, 403, 258-263. [CrossRef]

41. Kikuchi, G.; Motokawa, Y.; Yoshida, T.; Hiraga, K. Glycine cleavage system: Reaction mechanism, physiological significance, and hyperglycinemia. Proc. Jpn. Acad. Ser. B Phys. Biol. Sci. 2008, 84, 246-263. [CrossRef]

42. Matthews, D.E.; Conway, J.M.; Young, V.R.; Bier, D.M. Glycine nitrogen metabolism in man. Metabolism 1981, 30, 886-893. [CrossRef]

43. Skamarauskas, J.T.; Oakley, F.; Smith, F.E.; Bawn, C.; Dunn, M.; Vilder, D.S.; Clemence, M.; Blain, P.G.; Taylor, R.; Gamcsik, M.P.; et al. Noninvasive in vivo magnetic resonance measures of glutathione synthesis in human and rat liver as an oxidative stress biomarker. Hepatology 2014, 59, 2321-2330. [CrossRef] [PubMed]

44. Yoshida, T.; Kikuchi, G. Physiological significance of glycine cleavage system in human liver as revealed by the study of a case of hyperglycinemia. Biochem. Biophys. Res. Commun. 1969, 35, 577-583. [CrossRef]

45. Dasarathy, S.; Kasumov, T.; Edmison, J.M.; Gruca, L.L.; Bennett, C.; Duenas, C.; Marczewski, S.; McCullough, A.J.; Hanson, R.W.; Kalhan, S.C. Glycine and urea kinetics in nonalcoholic steatohepatitis in human: Effect of intralipid infusion. Am. J. Physiol. Gastrointest. Liver Physiol. 2009, 297, G567-G575. [CrossRef] [PubMed]

46. Walker, J.B. Repression of arginine-glycine transamidinase activity by dietary creatine. Biochim. Biophys. Acta 1959, 36, 574-575. [CrossRef]

47. McGuire, D.M.; Gross, M.D.; Elde, R.P.; van Pilsum, J.F. Localization of L-arginine-glycine amidinotransferase protein in rat tissues by immunofluorescence microscopy. J. Histochem. Cytochem. 1986, 34, 429-435. [CrossRef] [PubMed]

48. Pacana, T.; Cazanave, S.; Verdianelli, A.; Patel, V.; Min, H.K.; Mirshahi, F.; Quinlivan, E.; Sanyal, A.J. Dysregulated hepatic methionine metabolism drives homocysteine elevation in diet-induced nonalcoholic fatty liver disease. PLoS ONE 2015, 10, e0136822. [CrossRef] 
49. Hoyles, L.; Fernández-Real, J.M.; Federici, M.; Serino, M.; Abbott, J.; Charpentier, J.; Heymes, C.; Luque, J.L.; Anthony, E.; Barton, R.H.; et al. Molecular phenomics and metagenomics of hepatic steatosis in non-diabetic obese women. Nat. Med. 2018, 24, 1070-1080. [CrossRef]

50. Boll, M.; Daniel, H.; Gasnier, B. The SLC36 family: Proton-coupled transporters for the absorption of selected amino acids from extracellular and intracellular proteolysis. Pflug. Arch. 2004, 447, 776-779. [CrossRef]

51. Guastella, J.; Brechna, N.; Weigmann, C.; Lester, H.A.; Davidson, N. Cloning, expression and localization of a rat brain high-affinity glycine transporter. Proc. Natl. Acad. Sci. USA 1992, 89, 7189-7193. [CrossRef]

52. Liu, Q.R.; López-Corcuera, B.; Mandiyan, S.; Nelson, H.; Nelson, N. Cloning and expression of a spinal cordand brain-specific glycine transporter with novel structural features. J. Biol. Chem. 1993, 268, 22802-22808. [PubMed]

53. Zafra, F.; Aragon, C.; Gimenez, C. Molecular biology of glycinergic neurotransmission. Mol. Neurobiol. 1997, 14, 117-142. [CrossRef] [PubMed]

54. Kim, K.M.; Kingsmore, S.F.; Han, H.; Yang-Feng, T.L.; Godinot, N.; Seldin, M.F.; Caron, M.G.; Giros, B. Cloning of the human glycine transportertype 1: Molecular and pharmacological characterization of novel isoform variants and chromosomal localization of the gene in thehuman and mouse genomes. Mol. Pharmacol. 1994, 45, 608-617. [PubMed]

55. Bergeron, R.; Meyer, T.M.; Coyle, J.T.; Greene, R.W. Modulation of N-methyl-D-aspartate receptor function by glycine transport. Proc. Natl. Acad. Sci. USA 1998, 95, 15730-15734. [CrossRef] [PubMed]

56. Yue, J.T.; Abraham, M.A.; Bauer, P.V.; LaPierre, M.P.; Wang, P.; Duca, F.A.; Filippi, B.M.; Chan, O.; Lam, T.K. Inhibition of glycine transporter-1 in the dorsal vagal complex improves metabolic homeostasis in diabetes and obesity. Nat. Commun. 2016, 7, 13501. [CrossRef] [PubMed]

57. Howard, A.; Tahir, I.; Javed, S.; Waring, S.M.; Ford, D.; Hirst, B.H. Glycine transporter GLYT1 is essential for glycine-mediated protection of human intestinal epithelial cells against oxidative damage. J. Physiol. 2010, 588, 995-1009. [CrossRef]

58. Aroeira, R.I.; Sebastião, A.M.; Valente, C.A. GlyT1 and GlyT2 in brain astrocytes: Expression, distribution and function. Brain Struct. Funct. 2014, 219, 817-830. [CrossRef]

59. Xu, T.X.; Gong, N.; Xu, T.L. Inhibitors of GlyT1 and GlyT2 differentially modulate inhibitory transmission. Neuroreport 2005, 16, 1227-1231. [CrossRef]

60. Bröer, S. The SLC38 family of sodium-amino acid co-transporters. Pflug. Arch. 2014, 466, 155-172. [CrossRef]

61. Van der Sluis, R.; Badenhorst, C.P.; Erasmus, E.; van Dyk, E.; van der Westhuizen, F.H.; van Dik, A.A. Conservation of the coding regions of the glycine $\mathrm{N}$-acyltransferase gene further suggests that glycine conjugation is an essential detoxification pathway. Gene 2015, 571, 126-134. [CrossRef]

62. Badenhorst, C.P.S.; Erasmus, E.; van der Sluis, R.; Nortje, C.; van Dijk, A.A. A new perspective on the importance of glycine conjugation in the metabolism of aromatic acids. Drug Metab. Rev. 2014, 46, 343-361. [CrossRef] [PubMed]

63. Yan-Do, R.; MacDonald, P.E. Impaired "glycine"-mia in type 2 diabetes and potential mechanisms contributing to glucose homeostasis. Endocrinology 2017, 158, 1064-1073. [CrossRef] [PubMed]

64. Badenhorst, C.P.; van der Sluis, R.; Erasmus, E.; van Dijk, A.A. Glycine conjugation: Importance in metabolism, the role of glycine $\mathrm{N}$-acyltransferase, and factors that influence interindividual variation. Expert Opin. Drug Metab. Toxicol. 2013, 9, 1139-1153. [CrossRef] [PubMed]

65. Matsuo, M.; Terai, K.; Kameda, N.; Matsumoto, A.; Kurokawa, Y.; Funase, Y.; Nishikawa, K.; Sugaya, N.; Hitua, N.; Kishimoto, T. Designation of enzyme activity of glycine-N-acyltransferase family genes and depression of glycine-N-acyltransferase in human hepatocellular carcinoma. Biochem. Biophys. Res. Commun. 2012, 420, 901-906. [CrossRef] [PubMed]

66. Guo, C.; Xie, C.; Ding, P.; Qin, G.; Mo, W.; Cao, X.; Zheng, S. Quantification of glycocholic acid in human serum by stable isotope dilution ultra performance liquid chromatography electrospray ionization tandem mass spectrometry. J. Chromatogr. B 2018, 1072, 315-319. [CrossRef] [PubMed]

67. Falany, C.N.; Johnson, M.R.; Barnes, S.; Diasio, R.B. Glycine and Taurine Conjugation of Bile Acids by a Single Enzyme. Molecular cloning and expression of human liver bile acid CoA: Amino acid N-acyltransferase. J. Biol. Chem. 1994, 269, 19375-19379. [PubMed]

68. Solaas, K.; Ulvestad, A.; Söreide, O.; Kase, B.F. Subcellular organization of bile acid amidation in human liver: A key issue in regulating the biosynthesis of bile salts. J. Lipid Res. 2000, 41, 1154-1162. 
69. Pellicoro, A.; van den Heuvel, F.A.J.; Geuken, M.; Moshage, H.; Jansen, P.L.M.; Faber, K.N. Human and rat bile acid-CoA:amino acid $\mathrm{N}$-acyltransferase are liver-specific peroxisomal enzymes: Implications for intracellular bile salt transport. Hepatology 2007, 45, 340-348. [CrossRef]

70. Haeusler, R.A.; Camastra, S.; Nannipieri, M.; Astiarraga, B.; Castro-Perez, J.; Xie, D.; Wang, L.; Chakravarthy, M.; Ferrannini, E. Increased bile acid synthesis and impaired bile acid transport in human obesity. J. Clin. Endocrinol. Metab. 2016, 101, 1935-1944. [CrossRef]

71. Caspary, W.F. Increase of active transport of conjugated bile salts in streptozotocin-diabetic rat small intestine. Gut 1973, 14, 949-955. [CrossRef]

72. Okekunle, A.P.; Li, Y.; Liu, L.; Du, S.; Wu, X.; Chen, Y.; Li, Y.; Qi, J.; Sun, C.; Feng, R. Abnormal circulating amino acid profiles in multiple metabolic disorders. Diabetes Res. Clin. Pract. 2017, 132, 45-58. [CrossRef] [PubMed]

73. Perseghin, G.; Ghosh, S.; Gerow, K.; Shulman, G.I. Metabolic defects in lean nondiabetic offspring of NIDDM parents: A cross-sectional study. Diabetes 1997, 46, 1001-1009. [CrossRef] [PubMed]

74. Tulipani, S.; Griffin, J.; Palau-Rodriguez, M.; Mora-Cubillos, X.; Bernal-Lopez, R.M.; Tinahones, F.J.; Corkey, B.E.; Andres-Lacueva, C. Metabolomics-guided insights on bariatric surgery versus behavioral interventions for weight loss. Obesity (Silver Spring) 2016, 24, 2451-2466. [CrossRef] [PubMed]

75. Gralka, E.; Luchinat, C.; Tenori, L.; Ernst, B.; Thurnheer, M.; Schultes, B. Metabolomic fingerprint of severe obesity is dynamically affected by bariatric surgery in a procedure-dependent manner. Am. J. Clin. Nutr. 2015, 102, 1313-1322. [CrossRef] [PubMed]

76. Magkos, F.; Bradley, D.; Schweitzer, G.G.; Finck, B.N.; Eagon, J.C.; Ilkayeva, O.; Newgard, C.B.; Klein, S. Effect of Roux-en-Y gastric bypass and laparoscopic adjustable gastric banding on branched-chain amino acid metabolism. Diabetes 2013, 62, 2757-2761. [CrossRef] [PubMed]

77. Laferrère, B.; Reilly, D.; Arias, S.; Swerdlow, N.; Gorroochum, P.; Bawa, B.; Bose, M.; Teixeira, J.; Stevens, R.D.; et al. Differential metabolic impact of gastric bypass surgery versus dietary intervention in obese diabetic subjects despite identical weight loss. Sci. Transl. Med. 2011, 3, 80re2. [CrossRef] [PubMed]

78. Glynn, E.L.; Piner, L.W.; Huffman, K.M.; Slentz, C.A.; Elliot-Penry, L.; AbouAssi, H.; White, P.J.; Bain, J.R.; Muehlbauer, M.J.; Ilkayeva, O.R.; et al. Impact of combined resistance and aerobic exercise training on branched-chain amino acid turnover, glycine metabolism and insulin sensitivity in overweight humans. Diabetologia 2015, 58, 2324-2335. [CrossRef]

79. Wang-Sattler, R.; Yu, Z.; Herder, C.; Messias, A.C.; Floegel, A.; He, Y.; Heim, K.; Campillos, M.; Holzapfel, C.; Thorand, B.; et al. Novel biomarkers for pre-diabetes identified by metabolomics. Mol. Syst. Biol. 2012, 8, 615. [CrossRef]

80. Floegel, A.; Stefan, N.; Yu, Z.; Mühlenbruch, K.; Drogan, D.; Joost, H.G.; Fritsche, A.; Häring, H.U.; Hrabe de Angelis, M.; Peters, A.; et al. Identification of serum metabolites associated with risk of type 2 diabetes using a targeted metabolomic approach. Diabetes 2013, 62, 639-648. [CrossRef]

81. Palmer, N.D.; Stevens, R.D.; Antinozzi, P.A.; Anderson, A.; Bergman, R.N.; Wagenknecht, L.E.; Newgard, C.B.; Bowden, D.W. Metabolomic profile associated with insulin resistance and conversion to diabetes in the Insulin Resistance Atherosclerosis Study. J. Clin. Endocrinol. Metab. 2015, 100, E463-E468. [CrossRef]

82. Lever, M.; Slow, S.; McGregor, D.O.; Dellow, W.J.; George, P.M.; Chambers, S.T. Variability of plasma and urine betaine in diabetes mellitus and its relationship to methionine load test responses: An observational study. Cardiovasc. Diabetol. 2012, 11, 34. [CrossRef] [PubMed]

83. Lever, M.; George, P.M.; Slow, S.; Bellamy, D.; Young, J.M.; Ho, M.; McEntyre, C.J.; Emslie, J.L.; Atkinson, W.; Molyneux, S.L.; et al. Betaine and trimethylamine-N-oxide as predictors of cardiovascular outcomes show different patterns in diabetes mellitus: An observational study. PLoS ONE 2014, 9, e114969. [CrossRef] [PubMed]

84. Magnusson, M.; Wang, T.J.; Clish, C.; Engström, G.; Nilsson, P.; Gerszten, R.E.; Melander, O. Dimethylglycine deficiency and the development of diabetes mellitus. Diabetes 2015, 64, 3010-3016. [CrossRef] [PubMed]

85. Lever, M.; Slow, S. The clinical significance of betaine, an osmolyte with a key role in methyl group metabolism. Clin. Biochem. 2010, 43, 732-744. [CrossRef] [PubMed]

86. Yan, J.; Winter, L.B.; Burns-Whitmore, B.; Vermeylen, F.; Caudill, M.A. Plasma choline metabolites associate with metabolic stress among young overweight men in a genotype-specific manner. Nutr. Diabetes. 2012, 2, e49. [CrossRef] [PubMed] 
87. Ejaz, A.; Martinez-Guino, L.; Goldfine, A.B.; Ribas-Aulinas, F.; De Nigrus, V.; Ribo, S.; Gonzalez-Franquesa, A.; Garcia-Roves, P.M.; Li, E.; Dreyfuss, J.M.; et al. Dietary Betaine Supplementation Increases Fgf21 Levels to Improve Glucose Homeostasis and Reduce Hepatic Lipid Accumulation in Mice. Diabetes 2016, 65, 902-912. [CrossRef] [PubMed]

88. Walford, G.A.; Ma, Y.; Clish, C.; Florez, J.C.; Wang, T.J.; Gerszten, R.E.; Diabetes Prevention Program Research Group. Metabolite Profiles of Diabetes Incidence and Intervention Response in the Diabetes Prevention Program. Diabetes 2016, 65, 1424-1433. [CrossRef] [PubMed]

89. Svingen, G.F.; Schartum-Hansen, H.; Pedersen, E.R.; Ueland, P.M.; Tell, G.S.; Mellgren, G.; Njolstad, P.R.; Seifert, R.; Strand, E.; Karlsson, T.; et al. Prospective Associations of Systemic and Urinary Choline Metabolites with Incident Type 2 Diabetes. Clin. Chem. 2016, 62, 755-765. [CrossRef]

90. Stechemesser, L.; Eder, S.K.; Wagner, A.; Patsch, W.; Feldman, A.; Strasser, M.; Auer, S.; Niederseer, D.; Huber-Schönauer, U.; Paulweber, B.; et al. Metabolomic profiling identifies potential pathways involved in the interaction of iron homeostasis with glucose metabolism. Mol. Metab. 2016, 6, 38-47. [CrossRef]

91. Schartum-Hansen, H.; Ueland, P.M.; Pedersen, E.R.; Meyer, K.; Ebbing, M.; Bleie, O.; Svingen, G.F.; Seifert, R.; Nygard, $\mathrm{O}$. Assessment of urinary betaine as a marker of diabetes mellitus in cardiovascular patients. PLOS ONE 2013, 8, e69454. [CrossRef]

92. Mirmiran, P.; Bahadoran, Z.; Esfandyari, S.; Azizi, F. Dietary Protein and Amino Acid Profiles in Relation to Risk of Dysglycemia: Findings from a Prospective Population-Based Study. Nutrients 2017, 9, 971. [CrossRef] [PubMed]

93. Altorf-van der Kuil, W.; Brink, E.J.; Boetje, M.; Seibelink, E.; Bijlsma, S.; Engerink, M.F.; van't Veer, P.; Tomé, D.; Bakker, S.J.; van Baak, M.A.; et al. Identification of biomarkers for intake of protein from meat, dairy products and grains: A controlled dietary intervention study. Br. J. Nutr. 2013, 110, 810-822. [CrossRef] [PubMed]

94. O'Sullivan, A.; Gibney, M.J.; Brennan, L. Dietary intake patterns are reflected in metabolomic profiles: Potential role in dietary assessment studies. Am. J. Clin. Nutr. 2011, 93, 314-321. [CrossRef] [PubMed]

95. Wittenbecher, C.; Mühlenbruch, K.; Kröger, J.; Jacobs, S.; Kuxhaus, O.; Floegel, A.; Fritsche, A.; Pischon, T.; Prehn, C.; Adanski, J.; et al. Amino acids, lipid metabolites, and ferritin as potential mediators linking red meat consumption to type 2 diabetes. Am. J. Clin. Nutr. 2015, 101, 1241-1250. [CrossRef] [PubMed]

96. Gao, X.; Wang, Y.; Sun, G. High dietary choline and betaine intake is associated with low insulin resistance in the Newfoundland population. Nutrition 2017, 33, 28-34. [CrossRef]

97. Beaumont, M.; Portune, K.J.; Steuer, N.; Lan, A.; Cerrudo, V.; Audebert, M.; Dumont, F.; Mancano, G.; Khodorova, N.; Andriamihaja, M.; et al. Quantity and source of dietary protein influence metabolite production by gut microbiota and rectal mucosa gene expression: A randomized, parallel, double-blind trial in overweight humans. Am. J. Clin. Nutr. 2017, 106, 1005-1019. [CrossRef] [PubMed]

98. Dai, Z.L.; Li, X.L.; Xi, P.B.; Zhang, J.; Wu, G.; Zhu, W.Y. Metabolism of select amino acids in bacteria from the pig small intestine. Amino Acids 2012, 42, 1597-1608. [CrossRef]

99. Dai, Z.L.; Zhang, J.; Wu, G.; Zhu, W.Y. Utilization of amino acids by bacteria from the pig small intestine. Amino Acids 2010, 39, 1201-1215. [CrossRef]

100. Dai, Z.L.; Wu, G.; Zhu, W.Y. Amino acid metabolism in intestinal bacteria: Links between gut ecology and host health. Front. Biosci. (Landmark Ed.) 2011, 16, 1768-1786. [CrossRef]

101. Forslund, K.; Hildebrand, F.; Nielsen, T.; Falony, G.; Le Chatelier, E.; Sunagawa, S.; Prifti, E.; Vieira-Silva, S.; Gudmundsdottir, V.; Pedersen, H.K.; et al. Disentangling type 2 diabetes and metformin treatment signatures in the human gut microbiota. Nature 2015, 528, 262-266. [CrossRef]

102. Metges, C.C. Contribution of Microbial Amino Acids to Amino Acid Homeostasis of the Host. J. Nutr. 2000, 130, 1857S-1864S. [CrossRef] [PubMed]

103. Zhong, Y.; Nyman, M. Prebiotic and synbiotic effects on rats fed malted barley with selected bacteria strains. Food Nutr. Res. 2014, 58. [CrossRef] [PubMed]

104. Ndagijimana, M.; Laghi, L.; Vitali, B.; Placucci, G.; Brigidi, P.; Guerzoni, E. Effect of a synbiotic food consumption on human gut metabolic profiles evaluated by $1 \mathrm{H}$ Nuclear Magnetic Resonance spectroscopy. Int. J. Food Microbiol. 2009, 134, 147-153. [CrossRef] [PubMed]

105. Martin, F.P.; Wang, Y.; Sprenger, N.; Holmes, E.; Lindon, J.C.; Kochhar, S.; Nicholson, J.K. Effects of probiotic Lactobacillus paracasei treatment on the host gut tissue metabolic profiles probed via magic-angle-spinning NMR spectroscopy. J. Proteome Res. 2007, 6, 1471-1481. [CrossRef] [PubMed] 
106. Ma, N.; Tian, Y.; Wu, Y.; Ma, X. Contributions of the Interaction Between Dietary Protein and Gut Microbiota to Intestinal Health. Curr. Protein Pept. Sci. 2017, 18, 795-808. [CrossRef] [PubMed]

107. Beaumont, M.; Jaoui, D.; Douard, V.; Mat, D.; Koeth, F.; Goustard, B.; Mayeur, C.; Mondot, S.; Hovaghimian, A.; Le Feunteun, S.; et al. Structure of protein emulsion in food impacts intestinal microbiota, caecal luminal content composition and distal intestine characteristics in rats. Mol. Nutr. Food Res. 2017, 61. [CrossRef] [PubMed]

108. Neis, E.P.J.G.; Dejong, C.H.C.; Rensen, S.S. The Role of Microbial Amino Acid Metabolism in Host Metabolism. Nutrients 2015, 7, 2930-2946. [CrossRef]

109. Sommer, F.; Nookaew, I.; Sommer, N.; Fogelstrand, P.; Bäckhed, F. Site-specific programming of the host epithelial transcriptome by the gut microbiota. Genome Biol. 2015, 16, 62. [CrossRef]

110. Mardinoglu, A.; Shoaie, S.; Bergentall, M.; Ghaffari, P.; Zhang, C.; Larsson, E.; Bäckhed, F.; Nielsen, J. The gut microbiota modulates host amino acid and glutathione metabolism in mice. Mol. Syst. Biol. 2015, 11, 834. [CrossRef]

111. Jois, M.; Hall, B.; Fewer, K.; Brosnan, J.T. Regulation of hepatic glycine catabolism by glucagon. J. Biol. Chem. 1989, 264, 3347-3351.

112. Boden, G.; Rezvani, I.; Owen, O.E. Effects of glucagon on plasma amino acids. J. Clin. Investig. 1984, 73, 785-793. [CrossRef] [PubMed]

113. Gosmanov, N.R.; Gosmanov, A.R.; Gerich, J.E. Glucagon Physiology. In Endotext [Internet]; Feingold, K.R., Anawalt, B., Boyce, A., Chrousos, G., Dungan, K., Grossman, A., Hershman, J.M., Kaltsas, G., Koch, C., Kopp, P., et al., Eds.; MDText.com, Inc.: South Dartmouth, MA, USA, 2000.

114. White, P.J.; Lapworth, A.L.; An, J.; Wang, L.; McGarrah, R.W.; Stevens, R.D.; Ilkayeva, O.; George, T.; Muehlbauer, M.J.; Bain, J.R.; et al. Branched-chain amino acid restriction in Zucker-fatty rats improves muscle insulin sensitivity by enhancing efficiency of fatty acid oxidation and acyl-glycine export. Mol. Metab. 2016, 5, 538-551. [CrossRef] [PubMed]

115. She, P.; Van Horn, C.; Reid, T.; Hutson, S.M.; Cooney, R.N.; Lynch, C.J. Obesity-related elevations in plasma leucine are associated with alterations in enzymes involved in branched-chain amino acid metabolism. Am. J. Physiol. Endocrinol. Metab. 2007, 293, E1552-E1563. [CrossRef] [PubMed]

116. Lian, K.; Du, C.; Liu, Y.; Zhy, D.; Yan, W.; Zhang, H.; Hong, Z.; Liu, P.; Zhang, L.; Pei, H.; et al. Impaired adiponectin signaling contributes to disturbed catabolism of branched-chain amino acids in diabetic mice. Diabetes 2015, 64, 49-59. [CrossRef] [PubMed]

117. Lever, M.; Sizeland, P.C.; Bason, L.M.; Hayman, C.M.; Robson, R.A.; Chambers, S.T. Abnormal glycine betaine content of the blood and urine of diabetic and renal patients. Clin. Chim. Acta 1994, 230, 69-79. [CrossRef]

118. Csernus, K.; Lanyi, E.; Erhardt, E.; Molnar, D. Effect of childhood obesity and obesity-related cardiovascular risk factors on glomerular and tubular protein excretion. Eur. J. Pediatr. 2005, 164, 44-49. [CrossRef] [PubMed]

119. Xie, W.; Wood, A.R.; Lyssenko, V.; Weedon, M.N.; Knowles, J.W.; Alkayyali, S.; Assimes, T.L.; Questermous, T.; Abbasi, F.; Paananen, J.; et al. Genetic variants associated with glycine metabolism and their role in insulin sensitivity and type 2 diabetes. Diabetes 2013, 62, 2141-2150. [CrossRef]

120. Matone, A.; Scott-Boyer, M.P.; Carayol, J.; Fazelzadeh, P.; Fazelzadeh, P.; Lefebvre, G.; Valsesia, A.; Charon, C.; Vervoort, J.; Astrup, A.; et al. Network Analysis of Metabolite GWAS Hits: Implication of CPS1 and the Urea Cycle in Weight Maintenance. PLoS ONE 2016, 11, e0150495. [CrossRef]

121. Jia, Q.; Han, Y.; Huang, P.; Woodward, N.C.; Gukasyan, J.; Kettunen, J.; Ala-Korpela, M.; Anufrieva, O.; Wang, Q.; Perola, M.; et al. Genetic Determinants of Circulating Glycine Levels and Risk of Coronary Artery Disease. J. Am. Heart Assoc. 2019, 8, e011922. [CrossRef]

122. Gannon, M.C.; Nuttall, J.A.; Nuttall, F.Q. The metabolic response to ingested glycine. Am. J. Clin. Nutr. 2002, 76, 1302-1307. [CrossRef]

123. González-Ortiz, M.; Medina-Santillán, R.; Martínez-Abundis, E.; von Drateln, C.R. Effect of glycine on insulin secretion and action in healthy first-degree relatives of type 2 diabetes mellitus patients. Horm. Metab. Res. 2001, 33, 358-360. [CrossRef] [PubMed]

124. Nguyen, D.; Hsu, J.W.; Jahoor, F.; Sekhar, R.V. Effect of increasing glutathione with cysteine and glycine supplementation on mitochondrial fuel oxidation, insulin sensitivity, and body composition in older HIV-infected patients. J. Clin. Endocrinol. Metab. 2014, 99, 169-177. [CrossRef] [PubMed] 
125. Díaz-Flores, M.; Cruz, M.; Duran-Reyes, G.; Munquia-Miranda, C.; Loza-Rodriguez, H.; Pulido-Casas, E.; Torres-Ramirez, N.; Gaja-Rodriguez, O.; Kumate, J.; Baiza-Gutman, L.A.; et al. Oral supplementation with glycine reduces oxidative stress in patients with metabolic syndrome, improving their systolic blood pressure. Can. J. Physiol. Pharmacol. 2013, 91, 855-860. [CrossRef] [PubMed]

126. Du, J.; Shen, L.; Tan, Z.; Zhang, P.; Zhao, X.; Xu, Y.; Gan, M.; Yang, Q.; Ma, J.; Jiang, A.; et al. Betaine Supplementation Enhances Lipid Metabolism and Improves Insulin Resistance in Mice Fed a High-Fat Diet. Nutrients 2018, 10, 131. [CrossRef] [PubMed]

127. Grizales, A.M.; Patti, M.E.; Lin, A.P.; Beckman, J.A.; Sahni, V.A.; Cloutier, E.; Fowler, K.M.; Dreyfuss, J.M.; Pan, H.; Kozuka, C.; et al. Metabolic Effects of Betaine: A Randomized Clinical Trial of Betaine Supplementation in Prediabetes. J. Clin. Endocrinol. Metab. 2018, 103, 3038-3049. [CrossRef] [PubMed]

128. Zhou, X.; Han, D.; Xu, R.; Wu, H.; Qu, C.; Wang, F.; Wang, X.; Zhao, Y. Glycine protects against high sucrose and high fat-induced non-alcoholic steatohepatitis in rats. Oncotarget 2016, 7, 80223-80237. [CrossRef] [PubMed]

129. Takashima, S.; Ikejima, K.; Arai, K.; Yokokawa, J.; Kon, K.; Yamashina, S.; Watanabe, S. Glycine prevents metabolic steatohepatitis in diabetic KK-Ay mice through modulation of hepatic innate immunity. Am. J. Physiol. Gastrointest. Liver Physiol. 2016, 311, G1105-G1113. [CrossRef] [PubMed]

130. McCarty, M.F.; O’Keefe, J.H.; DiNicolantonio, J.J. Dietary Glycine Is Rate-Limiting for Glutathione Synthesis and May Have Broad Potential for Health Protection. Ochsner J. 2018, 18, 81-87. [PubMed]

131. Rani, V.; Deep, G.; Singh, R.K.; Palle, K.; Yadav, U.C. Oxidative stress and metabolic disorders: Pathogenesis and therapeutic strategies. Life Sci. 2016, 148, 183-193. [CrossRef]

132. Lutchmansingh, F.K.; Hsu, J.W.; Bennett, F.I.; Bardaloo, A.V.; McFarlane-Anderson, N.; Gordon-Strachan, G.M.; Wright-Pascoe, R.A.; Jahoor, F.; Boyne, M.S. Glutathione metabolism in type 2 diabetes and its relationship with microvascular complications and glycemia. PLOS ONE 2018, 13, e0198626. [CrossRef]

133. Furfaro, A.L.; Nitti, M.; Marengo, B.; Domenicotti, C.; Cottalasso, D.; Marinari, U.M.; Pronzato, M.A.; Traverso, N. Impaired synthesis contributes to diabetes-induced decrease in liver glutathione. Int. J. Mol. Med. 2012, 29, 899-905. [PubMed]

134. Sekhar, R.V.; McKay, S.V.; Patel, S.G.; Guthikonda, A.P.; Reddy, V.T.; Balasubramanyam, A.; Jahoor, F. Glutathione synthesis is diminished in patients with uncontrolled diabetes and restored by dietary supplementation with cysteine and glycine. Diabetes Care 2011, 34, 162-167. [CrossRef] [PubMed]

135. Chen, L.; Zhang, J.; Li, C.; Wang, Z.; Li, J.; Zhao, D.; Wang, S.; Zhang, H.; Huang, Y.; Guo, X. Glycine Transporter-1 and glycine receptor mediate the antioxidant effect of glycine in diabetic rat islets and INS-1 cells. Free Radic. Biol. Med. 2018, 123, 53-61. [CrossRef] [PubMed]

136. Bonkovsky, H.L.; Guo, J.T.; Hou, W.; Li, T.; Narang, T.; Thapar, M. Porphyrin and heme metabolism and the porphyrias. Compr. Physiol. 2013, 3, 365-401. [PubMed]

137. Garcia-Santos, D.; Schranzhofer, M.; Bergeron, R.; Sheftel, A.D.; Ponka, P. Extracellular glycine is necessary for optimal hemoglobinization of erythroid cells. Haematologica 2017, 102, 1314-1323. [CrossRef] [PubMed]

138. Converso, D.P.; Taillé, C.; Carreras, M.C.; Jaitovich, A.; Poderoso, J.J.; Boczkowski, J. HO-1 is located in liver mitochondria and modulates mitochondrial heme content and metabolism. FASEB J. 2006, 20, 1236-1238. [CrossRef] [PubMed]

139. Ridaura, V.K.; Faith, J.J.; Rey, F.E.; Cheng, J.; Duncan, A.E.; Kau, A.L.; Griffin, N.W.; Lombard, V.; Henrissat, B.; Bain, J.R.; et al. Gut microbiota from twins discordant for obesity modulate metabolism in mice. Science 2013, 341, 1241214. [CrossRef]

140. Koves, T.R.; Ussher, J.R.; Noland, R.C.; Slentz, D.; Mosedale, M.; Ilkayeva, O.; Bain, J.; Stevens, R.; Dyck, J.R.; Newgard, C.B.; et al. Mitochondrial overload and incomplete fatty acid oxidation contribute to skeletal muscle insulin resistance. Cell Metab. 2008, 7, 45-56. [CrossRef]

141. Pelantová, H.; Bugáňová, M.; Holubová, M.; Sediva, B.; Zemenova, J.; Sykora, D.; Kavalkova, P.; Haluzik, M.; Zelezna, B.; Maletinska, L.; et al. Urinary metabolomic profiling in mice with diet-induced obesity and type 2 diabetes mellitus after treatment with metformin, vildagliptin and their combination. Mol. Cell. Endocrinol. 2016, 431, 88-100. [CrossRef]

142. Mays, L.L.; Borek, E.; Finch, C.E. Glycine N-methyltransferase is a regulatory enzyme which increases in ageing animals. Nature 1973, 243, 411-413. [CrossRef] 
143. Wang, Y.C.; Chen, Y.M.; Lin, Y.J.; Liu, S.P.; Chiang, E.P. GNMT expression increases hepatic folate contents and folate-dependent methionine synthase-mediated homocysteine remethylation. Mol. Med. 2011, 17, 486-494. [CrossRef] [PubMed]

144. Wagner, C.; Briggs, W.T.; Cook, R.J. Inhibition of glycine N-methyltransferase activity by folate derivatives: Implications for regulation of methyl group metabolism. Biochem. Biophys. Res. Commun. 1985, 127, 746-752. [CrossRef]

145. Tseng, T.L.; Shih, Y.P.; Huang, Y.C.; Wang, C.K.; Chen, P.H.; Chang, J.G.; Yeh, K.T.; Chen, Y.M.; Buetow, K.H. Genotypic and phenotypic characterization of a putative tumor susceptibility gene, GNMT, in liver cancer. Cancer Res. 2003, 63, 647-654. [PubMed]

146. Borowa-Mazgaj, B.; de Conti, A.; Tryndyak, V.; Steward, C.R.; Jimenez, L.; Melnyk, S.; Seneshaw, M.; Mirshahi, F.; Rusyn, I.; Beland, F.A.; et al. Gene expression and DNA methylation alterations in the glycine N-methyltransferase gene in diet-induced nonalcoholic fatty liver disease-associated carcinogenesis. Toxicol. Sci. 2019, kfz110. [CrossRef] [PubMed]

147. Huidobro, C.; Toraño, E.G.; Fernández, A.F.; Urdinguio, R.G.; Rodríguez, R.M.; Ferrero, C.; Martínez-Camblor, P.; Boix, L.; Bruix, J.; García-Rodríguez, J.L.; et al. A DNA methylation signature associated with the epigenetic repression of glycine N-methyltransferase in human hepatocellular carcinoma. J. Mol. Med. (Berl.) 2013, 91, 939-950. [CrossRef] [PubMed]

148. Luka, Z.; Capdevila, A.; Mato, J.M.; Wagner, C. A glycine N-methyltransferase knockout mouse model for humans with deficiency of this enzyme. Transgenic Res. 2006, 15, 393-397. [CrossRef] [PubMed]

149. Liao, Y.J.; Liu, S.P.; Lee, C.M.; Yen, C.H.; Chuang, P.C.; Chen, C.Y.; Tsai, T.F.; Huang, S.F.; Lee, Y.H.; Chen, Y.M. Characterization of a glycine N-methyltransferase gene knockout mouse model for hepatocellular carcinoma: Implications of the gender disparity in liver cancer susceptibility. Int. J. Cancer 2009, 124, 816-826. [CrossRef]

150. Liao, Y.J.; Lee, T.S.; Twu, Y.C.; Hsu, S.M.; Yang, C.P.; Wang, C.K.; Liang, Y.C.; Chen, Y.A. Glycine $\mathrm{N}$-methyltransferase deficiency in female mice impairs insulin signaling and promotes gluconeogenesis by modulating the PI3K/Akt pathway in the liver. J. Biomed. Sci. 2016, 23, 69. [CrossRef]

151. Hughey, C.C.; Trefts, E.; Bracy, D.P.; James, F.D.; Donahue, E.P.; Wasserman, D.H. Glycine N-methyltransferase deletion in mice diverts carbon flux from gluconeogenesis to pathways that utilize excess methionine cycle intermediates. J. Biol. Chem. 2018, 293, 11944-11954. [CrossRef]

152. Young, A.B.; Snyder, S.H. Strychnine binding associated with glycine receptors of the central nervous system. Proc. Natl. Acad. Sci. USA 1973, 70, 2832-2836. [CrossRef]

153. Johnson, J.W.; Ascher, P. Glycine potentiates the NMDA response in cultured mouse brain neurons. Nature 1987, 325, 529-531. [CrossRef]

154. Lam, C.K.; Chari, M.; Su, B.B.; Cheung, G.W.; Kokorovic, A.; Yang, C.S.; Wang, P.Y.; Lai, T.Y.; Lam, T.K. Activation of N-methyl-D-aspartate (NMDA) receptors in the dorsal vagal complex lowers glucose production. J. Biol. Chem. 2010, 285, 21913-21921. [CrossRef] [PubMed]

155. Sorrels, T.L.; Bostock, E. Induction of feeding by 7-chlorokynurenic acid, a strychnine-insensitive glycine binding site antagonist. Brain Res. 1992, 572, 265-268. [CrossRef]

156. Manousopoulou, A.; Koutmani, Y.; Karaliota, S.; Woelk, C.H.; Manolakos, E.S.; Karalis, K.; Garbis, S.D. Hypothalamus proteomics from mouse models with obesity and anorexia reveals therapeutic targets of appetite regulation. Nutr. Diabetes 2016, 6, e204. [CrossRef] [PubMed]

157. Gameiro, A.; Reimann, F.; Habib, A.M.; O'Malley, D.; Williams, L.; Simpson, A.K.; Gribble, F.M. The neurotransmitters glycine and GABA stimulate glucagon-like peptide-1 release from the GLUTag cell line. J. Physiol. 2005, 569, 761-772. [CrossRef] [PubMed]

158. Yan-Do, R.; Duong, E.; Manning Fox, J.E.; Dai, X.; Suzuki, K.; Khan, S.; Bautista, A.; Ferdaoussi, M.; Lyon, J.; $\mathrm{Wu}, \mathrm{X}$; ; et al. A Glycine-Insulin Autocrine Feedback Loop Enhances Insulin Secretion from Human $\beta$-Cells and Is Impaired in Type 2 Diabetes. Diabetes 2016, 65, 2311-2321. [CrossRef] [PubMed]

159. Wheeler, M.D.; Ikejema, K.; Enomoto, N.; Stacklewitz, R.F.; Seabra, V.; Zhong, Z.; Yin, M.; Schemmer, P.; Rose, M.L.; Rusyn, I.; et al. Glycine: A new anti-inflammatory immunonutrient. Cell. Mol. Life Sci. 1999, 56, 843-856. [CrossRef] [PubMed] 
160. Jain, M.; Nilsson, R.; Sharma, S.; Madhusudhan, N.; Kitami, T.; Souza, A.L.; Kafri, R.; Kirschner, M.W.; Clish, C.B.; Mootha, V.K. Metabolite profiling identifies a key role for glycine in rapid cancer cell proliferation. Science 2012, 336, 1040-1044. [CrossRef]

161. Pirola, L.; Ciesielski, O.; Balcerczyk, A. The Methylation Status of the Epigenome: Its Emerging Role in the Regulation of Tumor Angiogenesis and Tumor Growth, and Potential for Drug Targeting. Cancers 2018, 10, 268. [CrossRef]

(c)

(C) 2019 by the authors. Licensee MDPI, Basel, Switzerland. This article is an open access article distributed under the terms and conditions of the Creative Commons Attribution (CC BY) license (http://creativecommons.org/licenses/by/4.0/). 